University of Florida Levin College of Law

UF Law Scholarship Repository

UF Law Faculty Publications

Faculty Scholarship

2020

\title{
The Rise and (Potential) Fall of U.S. Cartel Enforcement
}

Vivek Ghosal

D. Daniel Sokol

University of Florida Levin College of Law, sokold@law.ufl.edu

Follow this and additional works at: https://scholarship.law.ufl.edu/facultypub

Part of the Antitrust and Trade Regulation Commons

Recommended Citation

Vivek Ghosal \& D. Daniel Sokol, The Rise and (Potential) Fall of U.S. Cartel Enforcement, 2020 U. III. L. Rev. $471(2020)$

This Article is brought to you for free and open access by the Faculty Scholarship at UF Law Scholarship Repository. It has been accepted for inclusion in UF Law Faculty Publications by an authorized administrator of UF Law Scholarship Repository. For more information, please contact kaleita@law.ufl.edu. 


\title{
THE RISE AND (POTENTIAL) FALL OF U.S. CARTEL ENFORCEMENT
}

\author{
Vivek Ghosal \\ D. Daniel Sokol*
}

\begin{abstract}
Government enforcement against collusion, now viewed by the Supreme Court as the "supreme evil" in antitrust, has gone through various phases of enforcement in the United States. There have been periods in which cartels have been able to collude more or less effectively given various institutional tools at the disposal of the government. By analyzing enforcement and prosecutions data over a long time horizon, 1969-2016, this Article examines the attributes of cartel enforcement over time and the changing use of tools to assist with detection and punishment. We provide a comprehensive description of critical cartel enforcement events and institutional developments from 1890 to the present. Our examination of the data includes a detailed descriptive analysis which tends to reveal three broad phases of U.S. cartel enforcement and prosecutions. The most recent data indicate a marked decline in the number of prosecutions, but sharp increase in per capita penalties. We also conduct regression-based estimation of the potential quantitative impact of the key institutional innovations to foster detection and prosecutions. Based on the raw data as well as our estimation, we comment on the potential factors that may be driving lower prosecutions in the more recent years. Finally, we briefly compare some key data between U.S. and European Commission cartel prosecutions to examine potential dynamic interlinkages.
\end{abstract}

TABLE OF CONTENTS

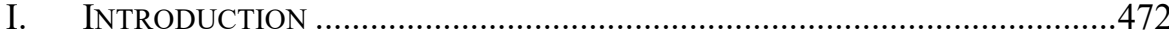

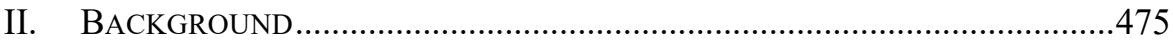

III. KEY DEVELOPMENTS IN U.S. CARTEL ENFORCEMENT ..............................477

IV. DATA DESCRIPTION AND INTERTEMPORAL PATTERNS.............................482

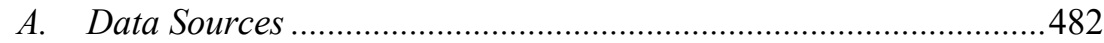

B. Intertemporal Patterns of Cartel Enforcement ................................484

V. EMPIRICAL FRAMEWORK AND ESTIMATION RESULTS...............................490

* Economics Department Head and Virginia and Lloyd W. Rittenhouse Professor of Humanities and Social Sciences, Rensselaer Polytechnic Institute.

**Professor, University of Florida Levin College of Law and Senior Advisor, White \& Case LLP.

We wish to thank conference participants at Yale Law School for their comments on an earlier version of this work. 
A. Empirical Framework

B. Estimation Results

VI. (Potential) DeCline of CARTEL ENFORCEMENT AND

PROSECUTIONS?

A. Leniency is a Success, There is More Internal Compliance, and There are Fewer Cartels

B. Cartels Have Gotten Smarter and Avoided Detection

C. Increased (Legal) Tacit Collusion

D. Shift From Greater Emphasis on Domestic Cartels to International Cartels...

E. Private Plaintiffs and States Have not Picked up the Local Bid Rigging and so This Goes Undetected .............................................498

F. State Enforcement is not Active Enough in Cartel Prosecutions ....499

G. Technological Innovation.

VII. COMPARISON OF U.S. AND EUROPEAN COMMISSION

CARTEL ENFORCEMENT 500

A. Examination of Dynamic Interrelationships Between U.S.-EC Cartel Enforcement

VIII. CONCLUSION

\section{INTRODUCTION}

Cartel enforcement, covering cases against price fixing, market allocation, and bid rigging, makes headlines. In 2017 alone, the U.S. Department of Justice ("DOJ") Antitrust Division fined Citicorp $\$ 925$ million, Barclays $\$ 650$ million, and JP Morgan $\$ 550$ million criminally for their participation in price fixing cartels. ${ }^{1}$ The loss to consumers that cartels create through collusion is unambiguous, so much so that the United States Supreme Court has called cartels the "the supreme evil of antitrust." 2 Yet, active enforcement against collusion was not always so, and also seems to be undergoing important shifts in recent years. This Article traces the evolution of the design of the institutional setting of U.S. cartel enforcement by examining its three major attributes: fines, criminal penalties, and leniency over time.

Since at least the 1970s, cartel enforcement started undergoing substantive transformation. Though Gary Becker did not explicitly mention antitrust in his foundational formulation of optimal deterrence, ${ }^{3}$ a number of scholars have applied Becker's framework to antitrust for more than a generation. ${ }^{4}$ The optimal

1. Sherman Act Violations Yielding a Corporate Fine of $\$ 10$ Million or More, U.S. DEP’T OF JUST., https://www.justice.gov/atr/sherman-act-violations-yielding-corporate-fine-10-million-or-more (last visited Jan. $18,2020)$.

2. Verizon Commc'ns Inc. v. Law Offices of Curtis V. Trinko, LLP, 540 U.S. 398, 408 (2004).

3. Gary S. Becker, Crime and Punishment: An Economic Approach, 76 J. Pol. ECON. 169 (1968).

4. See Michael K. Block et al., The Deterrent Effect of Antitrust Enforcement, 89 J. PoL. ECON. 429 (1981); Jean-Claude Bosch \& E. Woodrow Eckard Jr., The Profitability of Price Fixing: Evidence from Stock Market Reaction to Federal Indictments, 73 REV. ECON. \& STAT. 309, 315-17 (1991); Robert M. Feinberg, Antitrust Enforcement and Subsequent Price Behaviour, 62 REV. ECON. \& STAT. 609 (1980); William M. Landes, 
deterrence framework, whether implicit or explicit, has pervaded formulation of antitrust scholars and policy-makers in their approach to issues of institutional design regarding cartel detection and prosecution.

This Article analyzes transformations of cartel policy using an optimal deterrence framework. Government cartel prosecution policy shifts occurred at roughly the same time that much of doctrinal antitrust underwent significant transformation. ${ }^{5}$ The doctrinal and policy shifts in antitrust were part of an intellectual shift due to Chicago law and economics scholars as well as Harvard legal process scholars. ${ }^{6}$ Together, these groups of scholars advocated for a fundamental change to the existing regime of U.S. antitrust law and policy. This included a clear focus on economic effects, ${ }^{7}$ and a shift in civil conduct liability from per se illegality to a more lenient rule of reason as a result of potential efficiencies of the particular business practice. ${ }^{8}$

The contribution of this Article is twofold. First, we analyze the various cartel policy regimes over time. In doing so, we quantify the effects of the various policy regimes on the number of cartels prosecuted, as well as the financial penalties per individual and firm and the impact on number of days in jail for cartel crimes. Our research offers an empirical basis that builds off of prior theoretical literature that examines the impact to deterrence based on enforcement tools and cartel formation. ${ }^{9}$ Moreover, a series of articles have modeled incentives or have

Optimal Sanctions for Antitrust Violations, 50 U. CHI. L. REV. 652, 656-57 (1983); D. Daniel Sokol, Policing the Firm, 89 Notre Dame L. Rev. 785 (2014); John S. Thompson \& David L. Kaserman, After the Fall: Stock Price Movements and the Deterrent Effect of Antitrust Enforcement, 19 REV. INDUS. ORG. 329, 331 (2001).

5. See generally Frank H. Easterbrook, The Limits of Antitrust, 63 TEX. L. REV. (1984); William E. Kovacic \& Carl Shapiro, Antitrust Policy: A Century of Economic and Legal Thinking, 14 J. ECON. PERSP. 43 (2000); Barak Y. Orbach, The Antitrust Consumer Welfare Paradox, 7 J. COMPETITION L. \& ECON. 133 (2010).

6. See Jonathan B. Baker, Competition Policy as a Political Bargain, 73 ANTITRUST L.J. 483, 512 n. 109 (2006) ("Post-Chicago criticisms of current antitrust doctrine largely accept the economic approach, and call for modifications to existing rules based upon the application of game theoretic tools and new empirical economic methods."); Herbert Hovenkamp, Harvard, Chicago and Transaction Cost Economics in Antitrust Analysis, 55 ANTITRUST BULl. 613, 617-18 (2010) ("Since the 1970s both the old Harvard and the traditional Chicago positions have moved from opposite directions toward the center, partly as a result of the influence of transaction cost analysis. Today their differences on many issues are not all that considerable."); William E. Kovacic, The Intellectual DNA of Modern U.S. Competition Law for Dominant Firm Conduct: The Chicago/Harvard Double Helix, 2007 Colum. Bus. L. ReV. 1 (2007); Donald Turner, The Durability, Relevance, and Future of American Antitrust Policy, 75 CALIF. L. REV. 797, 798 (1987) ("[Non-economic goals] would broaden antitrust's proscriptions to cover business conduct that has no significant anticompetitive effects, would increase vagueness in the law, and would discourage conduct that promotes efficiencies not easily recognized or proved.").

7. See Robert H. Bork, The Antitrust Paradox: A Policy at War with itself 50-51 (1978); Roger D. Blair \& D. Daniel Sokol, Welfare Standards in U.S. and E.U. Antitrust Enforcement, 81 ForDHAM L. REV. 2497, 2506-07 (2013). But see HERBERT HOVENKAMP, ENTERPRISE AND AMERICAN LAW, 1836-1937, 268 (1991) ("One of the great myths about American antitrust policy is that courts began to adopt an 'economic approach' to antitrust problems only in the 1970's. At most, this 'revolution' in antitrust policy represented a change in economic models. Antitrust policy has been forged by economic ideology since its inception.").

8. See Andrew I. Gavil, Moving Beyond Caricature and Characterization: The Modern Rule of Reason in Practice, 85 S. CAL. L. REV. 733, 734 (2012); Richard Posner, The Rule of Reason and the Economic Approach: Reflections on the Sylvania Decision, 45 U. CHI. L. REV. 1 (1977); D. Daniel Sokol, The Transformation of Vertical Restraints: Per Se Illegality, the Rule of Reason, and Per Se Legality, 79 ANTITRUST L.J. 1003 (2014).

9. See generally Joseph E. Harrington Jr. \& Myong-Hun Chang, When Should We Expect a Corporate Leniency Program to Result in Fewer Cartels, 58 J.L. \& ECON. 417 (2015); Nathan H. Miller, Strategic Leniency and Cartel Enforcement, 99 AM. ECON. REV. 750 (2009). 
offered experimental evidence under leniency to improve cartel detection due to the destabilizing effect that leniency may have on cartel duration. ${ }^{10}$ Through our examination of alternative cartel prosecution regimes, we extend the existing empirical work in the area of cartel stability and duration. To the best of our knowledge, we provide the longest time-series data analysis for the various facets of cartel enforcement by the DOJ.

Second, we offer an analysis of political effects of cartel enforcement. We extend prior work that examines political preferences in cartel prosecutions. ${ }^{11}$ Due to the time-series data that we use covering the Nixon through Obama presidencies, we can examine both inter-political party as well as intra-political party effects on cartel prosecution. Examining specific presidential administrations, the data shows significant variations between Republican and Democratic administrations, as well as within each party. Our empirical analysis provides a basis to study how overall policy differences across administrations and political parties also extends to cartel prosecutions.

Cartel enforcement and specifically questions of cartel detection and stability are difficult ones to address for researchers. Since the 1960s, theorists have questioned cartel stability ${ }^{12}$ while empiricists have worked to better understand cartel dynamics. ${ }^{13}$ A major hurdle that confounds empirical work on cartel detection and duration assumes that it is possible to determine the overall number of cartels (a "denominator" problem). ${ }^{14}$ Cartels require an agreement by cartel members to collude. Yet, because such collusion is illegal, the agreements or contracts to collude are unenforceable by law and are instead concealed. Because of this concealment, it is difficult to determine the total number of cartels that exist at any given point in time. ${ }^{15}$ What empirical analysis can create in terms of a measurement proxy for cartel existence and stability is the total number of cartel prosecutions by the government. These criminal prosecutions are based on hard evidence of collusion. In more recent years, evidence of collusion has tended to emerge as a result of a defendant who defects from a cartel via the

10. Maria Bigoni et al., Trust, Leniency, and Deterrence, 31 J.L. \& ECON. \& ORG. 663 (2015); Yasuyo Hamaguchi et al., Group Size Effects on Cartel Formation and the Enforcement Power of Leniency Programs, 27 InT'L J. INDUS. ORG. 145 (2009); Joseph E. Harrington, Jr., Optimal Corporate Leniency Programs, 56 J. INDUS. ECON. 215 (2008).

11. See Vivek Ghosal \& D. Daniel Sokol, Policy Innovations, Political Preferences, and Cartel Prosecutions, 48 REV. INDUST. ORG. 405 (2016).

12. See generally Jay Pil Choi \& Heiko Gerlach, Cartels and Collusion: Economic Theory and Experimental Economics, in OXFORD HANDBOOK OF INTERNATIONAL ANTITRUST ECONOMICS, vol. 2 (Roger D. Blair \& D. Daniel Sokol, eds., 2014) (providing an overview of the theoretical literature).

13. See generally Andrew R. Dick, When Are Cartels Stable Contracts?, 39 J.L. \& ECON. 241 (1996); Vivek Ghosal \& D. Daniel Sokol, The Evolution of U.S. Cartel Enforcement, 57 J.L. \& ECON. S51, S51-54 (2014); Margaret C. Levenstein \& Valerie Y. Suslow, Breaking Up Is Hard to Do: Determinants of Cartel Duration, 54 J.L. \& ECON. 455, 456 (2011); Margaret C. Levenstein \& Valerie Y. Suslow, What Determines Cartel Success?, 44 J. ECON. LIT. 43, 44, 74 (2006).

14. See Ghosal \& Sokol, supra note 13, at S55 n.8.

15. Merger evaluation for example is a very different problem as the U.S. Merger Guidelines explicitly require companies to file for Government clearance when the transaction is above a stated value. Even if a merger is below the stated value, this information is readily visible, and antitrust authorities can investigate and challenge such a merger. The cartel problem is different as we literally have no idea about how many cartels are actually operating. 
leniency program to cooperate with the DOJ for a reduction in penalties. ${ }^{16}$ Historically, however, the genesis of cartel investigations have been based on more diverse sources of information flows. ${ }^{17}$

We organize this Article as follows: In Part II, we provide a background of the intellectual context for cartel enforcement. Next, in Part III, we provide descriptive analysis of critical cartel enforcement events and institutional developments from 1890 to the present. ${ }^{18}$ Thereafter, we describe the data and intertemporal patterns in cartel enforcement in Part IV. In Part V, we develop the empirical specification and present the estimation results. In Part VI, we discuss whether there has been a potential decline in cartel enforcement in the U.S., given our data and findings. Next, in Part VII, we briefly compare some key data between U.S. and European Commission cartel prosecutions. Finally, we offer concluding remarks in Part VIII.

\section{BACKGROUND}

The Chicago School transformed antitrust. ${ }^{19}$ Cartel enforcement played a smaller role for the Chicago School overall, which focused on the reform of merger and monopolization enforcement. ${ }^{20}$ The lack of emphasis on cartels was due both in part to the overall confusion by the courts as to other areas of law as well as to the fact that conceptually cartel enforcement was "low hanging fruit": the identification of harm by cartel behavior from the standpoint of consumer welfare was simple. ${ }^{21}$ The per se application of liability to hardcore cartels made them less effective and destabilized them. The present structure of cartel enforcement with high fines, significant incarceration, an emphasis on enforcement against large international cartels, and the use of leniency, is very different from

16. Scott Hammond, Deputy Assistant Gen. for Criminal Enf’t Antitrust Div., U.S. Dep't of Justice, Address before the 24th Annual National Institute on White Collar Crime, The Evolution of Criminal Antitrust Enforcement Over the Last Two Decades (Feb. 25, 2010), https:/www.justice.gov/atr/file/518241/download.

17. Vivek Ghosal, The Genesis of Cartel Investigations: Some Insights from Examining the Dynamic Interrelationships Between U.S. Civil and Criminal Antitrust Investigations, 3 J. COMP. L. \& ECON. 61, 64 (2008),

18. We limit our analysis to federal cartel prosecution. But see Robert M. Feinberg \& Kara M. Reynolds, The Determinants of State Level Antitrust Activity, 37 REV. INDUS. ORG. 179 (2010) (examining state level enforcement).

19. See generally Robert H. Bork, The Rule of Reason and the Per Se Concept: Price Fixing and Market Division, 75 YALE L.J. 373 (1966); Ward S. Bowman, Jr., The Prerequisites and Effects of Resale Price Maintenance, 22 U. CHI. L. ReV. 825 (1955); Daniel A. Crane, Chicago, Post-Chicago, and Neo-Chicago, 76 U. CHI. L. REV. 1911 (2009); Frank H. Easterbrook, Predatory Strategies and Counterstrategies, 48 U. CHI. L. REV. 263, 264 (1981); Easterbrook, supra note 5; David S. Evans \& A. Jorge Padilla, Designing Antitrust Rules for Assessing Unilateral Practices: A Neo-Chicago Approach, 72 U. CHI. L. REV. 73, 74-75 (2005); Benjamin Klein \& Kevin M. Murphy, Vertical Restraints as Contract Enforcement Mechanisms, 31 J.L. \& ECON. 265 (1988); William H. Page, The Chicago School and the Evolution of Antitrust: Characterization, Antitrust Injury, and Evidentiary Sufficiency, 75 VA. L. REV. 1221 (1989); Sam Peltzman, Aaron Director's Influence on Antitrust Policy, 48 J.L. \& ECON. 313 (2005); Richard A. Posner, The Chicago School of Antitrust Analysis, 127 U. PA. L. REV. 925 (1979); Richard A. Posner, The Next Step in the Antitrust Treatment of Restricted Distribution: Per Se Legality, 48 U. CHI. L. REV. 6 (1981); George J. Stigler, The Economic Effects of the Antitrust Laws, 9 J.L. \& ECON. 225 (1966); Lester G. Telser, Why Should Manufacturers Want Fair Trade?, 3 J.L. \& ECON. 86 (1960).

20. See BORK, supra note 7.

21. See Ghosal \& Sokol, supra note 13 , at S54. 
the primary topics that concerned academic writing from Chicago or other scholars until the $1990 \mathrm{~s}^{22}$

In the early formulation of antitrust, three thinkers dominated cartel related thought, all from the Chicago tradition: Stigler, Bork, and Posner. Stigler noted that collusion was possible but believed that cartels would break down easily. He offered a theory of equilibrium in a dynamic noncooperative game. ${ }^{23}$ While Stigler contributed to thinking about coordinated effects in mergers, the application to cartel enforcement was limited because the implication of his work is exogenous conditions for each industry would determine firm interaction but explicit collusion was difficult. ${ }^{24}$

Of the other Chicago theorists, Bork offered a holistic approach to antitrust reform in the Antitrust Paradox. Bork's discussion of explicit collusion in the book was surprisingly short. Indeed, Bork wrote less than a paragraph on the topic of explicit collusion in his chapter on horizontal restraints. ${ }^{25}$ The horizontal restraints chapter instead focused on ancillary restraints where collusive behavior had offsetting efficiencies that were greater than the anti-competitive restraints. ${ }^{26}$ In the policy chapter of the Antitrust Paradox, Bork's cartel discussion also was brief. He suggested that the DOJ open more field offices across the country to prosecute local cartels. ${ }^{27}$ Bork's rather short treatment of cartels reflected that as a matter of law and policy, cartels were both conceptually and doctrinally easy situations to rectify.

Bork's short treatment of cartels left unaddressed a number of significant features about the institutional structure of cartel enforcement (leniency, increased fines, and increased incarceration) that were in place by the time of the publication in 1978 of the Antitrust Paradox. ${ }^{28}$ Moreover, he ignored international cartel issues, which by the late 1970 s were beginning to become more significant. $^{29}$

The third major Chicago thinker theorizing about collusion was Richard Posner. His early writing focused on tacit collusion as well as government antitrust enforcement. ${ }^{30}$ In his antitrust casebook (both original 1976 edition and 2001 revised edition), ${ }^{31}$ Posner argued against jail time for cartel crimes. Instead, he supported higher fines as a penalty for cartel activity. ${ }^{32}$ Encouragement for

\footnotetext{
22. See id. at S63-64.

23. Dennis W. Carlton \& Sam Peltzman, Introduction to Stigler's Theory of Oligopoly, 6 COMPETITION POL'Y INT'L 239 (2010); George J. Stigler, A Theory of Oligopoly, 72 J. POL. ECON. 44 (1964).

24. Sokol, supra note 4 , at 817.

25. See BORK, supra note 7 , at 268.

26. Bork had concerns about misapplication of per se rules to cases. See, e.g., United States v. Topco Assocs., Inc., 405 U.S. 596 (1972); United States v. Sealy, Inc., 388 U.S. 350 (1967).

27. See BoRK, supra note 7, at 406-07.

28. See Ghosal \& Sokol, supra note 13, at S53.

29. Id.

30. See, e.g., Richard A. Posner, A Program for the Antitrust Division, 38 U. CHI. L. REV. 500 (1971); Richard A. Posner, A Statistical Study of Antitrust Enforcement, 13 J.L. \& ECON. 365 (1970); Richard A. Posner, Oligopoly and the Antitrust Laws: A Suggested Approach, 21 STAN. L. REV. 1562 (1969).

31. Richard A. Posner, ANTitrust Law 270 (2d ed. 2001) [hereinafter ANTITRUst Law]; Richard A. Posner, Antitrust Law: An ECONOMic Perspective 225 (1976).

32. ANTITRUST LAW, supra note 31 , at 270 .
} 
higher fines suggests a view of suboptimal cartel enforcement. Particularly noteworthy, with the revised edition of his casebook, Posner continued to believe that antitrust enforcement was suboptimal even with a change of higher fines and significant increased cartel detection among local bid rigging cartels in the 1980s and international cartels in the $1990 \mathrm{~s}^{33}$

Comparing Posner and Bork, on the three points that Posner specifically raised: (a) broadening legal liability for plus factors regarding tacit collusion, ${ }^{34}$ (b) increased criminal fines (Posner favored increased fines even after the 1974 Antitrust Procedures and Penalties Act), ${ }^{35}$ and (c) the use of incarceration (Posner opposed it), Bork was silent on the last two. ${ }^{36}$ We interpret the silence of Bork on these issues to necessitate that Bork believed cartel enforcement was suboptimal but for reasons different than Posner. If cartel enforcement approached optimality, advocacy of additional DOJ Antitrust field offices would have been unnecessary. Thus, Bork's belief in suboptimal cartel enforcement focused on the likelihood of detection rather than on increased penalties (incarceration and/or fines). ${ }^{37}$

The current institutional structure of cartel enforcement with high fines, significant incarceration for individuals, a prosecution emphasis on large international cartels rather than small local cartels, and the reliance on leniency for cartel detection is very different from what concerned Stigler, Bork, or Posner.

\section{Key DeVelopments In U.S. CARTEL ENFORCEMENT}

The time period of 1960-1978 witnessed important structural shifts in the institutions of government cartel enforcement. ${ }^{38}$ There were three shifts in terms of government enforcement: fines, incarceration, and the introduction of a leniency program. The shifts to higher financial penalties, greater criminal sanctions,

33. Id. at 266 .

34. More recently, Posner has changed his view on tacit collusion and plus factors. See Richard A. Posner, Review of Kaplow, Competition Policy and Price Fixing, 79 ANTITRUST L.J. 761, 763 (2014) (reviewing Louis Kaplow, Competition Policy and Price Fixing (2013)).

35. Regarding incarceration, in late 1976, Don Baker, the then Assistant Attorney General for Antitrust, presented a speech advocating a significant increase in the use and severity of criminal antitrust. Don Baker, To Make the Penalty Fit the Crime: How to Sentence Antitrust Felons, Remarks as Prepared for the Tenth New England Antitrust Conference (Nov. 20, 1976), in SHERMAN ACT INDICTMENTS: 1955-1980 vol. 2, at 530 (James M. Clabault \& Michael K. Block eds., 1981). Consequently, the Antitrust Division promulgated guidelines that pushed for greater severity of criminal enforcement. See U.S Dep't of Justice Guidelines for Sentencing: Recommendations in Felony Cases Under the Sherman Act, in SHERMAN ACT INDICTMENTS: 1955-1980 vol. 2, at 550 (James M. Clabault \& Michael K. Block eds., 1981).

36. See Ghosal \& Sokol, supra note 13, at S55.

37. Bork's policy prescription of increased cartel enforcement via additional DOJ field offices suggests that Bork may have been less convinced than Stigler of the inherent instability of cartels. See Stigler, supra note 23, at 61. That is, if cartels naturally fail, the case for increased cartel enforcement via more staffing of regional field offices would be weak. Subsequent research into cartels suggests that cartels are more successful than Stigler may have anticipated. See Levenstein \& Suslow, supra note 13, at 456.

38. See Ghosal \& Sokol, supra note 13, at S55. 
and leniency ${ }^{39}$ were changes to increase probability of detection and severity of punishment associated with cartel behavior. Cartel related criminal fines, which had been raised in the 1950s for the very first time since 1890, even when adjusted for inflation, seem low by today's standards. ${ }^{40}$ Additionally, cartel behavior was treated as a misdemeanor rather than a felony. From a moral standpoint, shifting a crime from a misdemeanor to a felony also increased moral/reputational stigma for such crime. ${ }^{41}$ Leniency created the possibility of a reward for a firm defecting from a cartel. ${ }^{42}$

To motivate the empirical analysis in Part V, we offer an overview of the significant events in the timeline of cartel policy. Enforcement began with the passage of the Sherman Act. ${ }^{43}$ Under the Sherman Act, the maximum fine for collusion was set at $\$ 5,000 .{ }^{44}$ After a half century of fines at the same level, Congress raised the maximum fine in 1955 to $\$ 50,000$ per count. ${ }^{45}$ Incarceration was not used much in antitrust's first half century. ${ }^{46}$ Starting in the late $1950 \mathrm{~s}$, however, the DOJ began an enforcement shift to greater incarceration for collusion. ${ }^{47}$ For example, United States v. McDonough Co. yielded the incarceration of four executives. ${ }^{48}$

Cartel enforcement became more robust in the period from 1958-1961 due to the electrical equipment price fixing cases. ${ }^{49}$ These collusion cases involved thirty corporations and forty-five defendants. ${ }^{50}$

The cases received significant public attention due to the size of the overcharges, the high profile companies involved in the collusion, and the relatively small financial penalties and jail time for "respectable" people. ${ }^{51}$ To put the fines in perspective, Professor Connor explains regarding the penalties, "[c]orporate antitrust convictions were the equivalent of corporate parking tickets."

Due to the low penalties - both monetary and incarceration - imposed in the 1950s and 1960s, legislative changes were introduced during the 1970s to

39. It was during this period that DOJ introduced the first iteration of the leniency program. Though the original leniency program was introduced in 1978, DOJ Antitrust had been discussing the leniency program since 1976, according to senior DOJ Antitrust officials at the time with whom we conferred.

40. See Ghosal \& Sokol, supra note 13 , at S55.

41. See generally Criminalization The Political Morality of the Criminal Law (R.A. Duff, Lindsay Farmer, S.E. Marshall, Massimo Renzo \& Victor Tadros eds., 2014).

42. See Maria Bigoni et al., Fines, Leniency and Rewards in Antitrust: An Experiment, 43 RAND J. ECON. 368,370 (2012).

43. Sherman Act, Pub. L. No. 97-290, 96 Stat. 1246 (1982) (codified at 15 U.S.C. § 6a (2018)).

44. See Ghosal \& Sokol, supra note 13, at S55.

45. See Sherman Act, Pub. L. No. 135, 26 Stat. 209 (1955); Ghosal \& Sokol, supra note 13, at S55.

46. Gregory J. Werden, Individual Accountability Under the Sherman Act: The Early Years, 31 ANTITRUST 100, 103 (2017).

47. Ghosal \& Sokol, supra note 13 , at S55.

48. 180 F. Supp. 511, 514 (S.D. Ohio 1959).

49. Ghosal \& Sokol, supra note 13, at S55.

50. $I d$.

51. See generally Gilbert Geis, The Heavy Electrical Equipment Antitrust Cases of 1961, in WHITECollar Crime: OfFenses in Business, Politics, AND the Professions 117 (Gilbert Geis \& Robert F. Meier eds., 1977).

52. John M. Connor, Global Price Fixing: Our Customers Are the ENEMY 43 (2001). 
increase the severity of punishment. In 1974, Congress enacted the Antitrust Procedures and Penalties Act. ${ }^{53}$ Among the things covered under the Act were cartel related enforcement issues. Collusion was reclassified a felony from merely a misdemeanor. Further, the maximum financial penalty for collusive behavior was increased to $\$ 1$ million. ${ }^{54}$ It took only a few years for the higher penalties to be implemented in cartel cases. In the United States v. Continental Group, Inc. cases, the DOJ secured the first set of felony convictions for collusion at trial with the maximum felony sentence imposed. ${ }^{55}$

Responding to a lack of effective detection, the DOJ created its initial leniency program. The leniency program, launched by the DOJ in 1978, created a system in which a firm could defect from a cartel and receive a reduced penalty from the DOJ if it came forward with information about the cartel. ${ }^{56}$ Because of the design of the leniency program, however, this iteration was ineffective. ${ }^{57}$

Significant changes in cartel enforcement occurred in terms of the number of cases prosecuted under Reagan as well as case prioritization for merger and civil enforcement. ${ }^{58}$ Data show that civil Sherman Section 1 and 2 government enforcement significantly diminished. ${ }^{59}$ The creation in 1982 of the Horizontal Merger Guidelines, revised in 1984, also altered antitrust enforcement by increasing the number of merger filings. ${ }^{60}$ These shifts in DOJ Antitrust resources impacted cartel enforcement. ${ }^{61}$ As a result, criminal enforcement increased under Reagan in terms of the number of cases and marginally in terms of penalties imposed. $^{62}$

Further tweaks to the structure of enforcement occurred in 1984, when Congress passed the Criminal Fine Enforcement Act. The Act increased individual fines to $\$ 250,000 .{ }^{63}$ Further penalty enhancement came in 1987 as a result of the

\footnotetext{
53. Antitrust Procedures and Penalties Act, Pub. L. No. 93-528, 88 Stat. 1706 (1974).

54. Ghosal \& Sokol, supra note 13, at S56.

55. 603 F.2d 444 (3d Cir. 1980).

56. Scott Hammond, Dir. of Criminal Enforcement, Antitrust Div., U.S. Dep't of Justice, Cornerstones of an Effective Leniency Program, at 3 n.1 (Nov. 22-23, 2004).

57. Only one leniency application was received per year and not a single leniency application was for an international cartel. See id. at 3. An important issue also is that DOJ's resource allocation changed shortly after the introduction of leniency. In 1979, the Hart Scott Rodino Act of 1976 went through its first full year of implementation. The first year of merger filing notifications totaled over 800 filings. Increasingly, merger control became far more resource intensive, potentially distracting from other areas of enforcement. Ghosal \& Sokol, Evolution, supra note 13, at S57 n.10.

58. Ghosal \& Sokol, supra note 13 , at S57-58.

59. $I d$.

60. Id.

61. In 1982, Congress passed the FTAIA to clarify the extraterritorial application of the Sherman Act. See Sherman Act, Pub. L. No. 97-290, 96 Stat. 1246 (codified as amended at 15 U.S.C. § 6a (2018)).

62. U.S. v. B\&B Construction Co. (1981) marked the first time maximum prison terms were imposed under the 1974 statute. Much of the cartel enforcement in the 1980s and early 1990s appeared to have focused on procurement and infrastructure collusion. William E. Kovacic, Criminal Enforcement Norms in Competition Policy: Insights from US Experience, in CRIMINALISING CARTELS: CRITICAL STUDIES OF AN INTERNATIONAL Regulatory Movement 45, 65-66 (CARON BeAton-Wells \& Ariel Ezrachi eds., 2011).

63. Criminal Fine Enforcement Act of 1984, Pub. L. No. 98-596, 98 Stat. 3134 (reenacted as Criminal Fine Improvements Act of 1987, Pub. L. No. 100-185, 101 Stat. 1279 (codified as amended at 18 U.S.C. $\S 3571(\mathrm{~d})(2018)))$.
} 
U.S. Sentencing Guidelines (passed in 1984), which were applied to all cartel offenses. ${ }^{64}$ Even further changes to cartel enforcement came later with the passage of the Antitrust Amendments Act of $1990 .^{65}$ The Act increased maximum fines for collusion to $\$ 10$ million for corporations and $\$ 350,000$ for individuals. ${ }^{66}$ The Act also increased prison terms up to three years. ${ }^{67}$

The 1990s witnessed a transformation of cartel detection mechanisms. The fundamental change to cartel prosecution occurred in 1993 when the DOJ revised its leniency program. ${ }^{68}$ Under the revised leniency program, the DOJ offered a leniency applicant automatic amnesty under two settings: 1) if there was no pre-existing cartel investigation, and 2) if there was full cooperation. ${ }^{69}$ Further, amnesty was available to a leniency applicant even when cooperation with the DOJ began after an investigation had already been initiated. ${ }^{70}$ Finally, in the situation when the corporation qualified for automatic amnesty, the DOJ provided for automatic amnesty based on full cooperation of all directors, officers, and employees. ${ }^{71}$

Unlike the prior iteration of leniency, this version of leniency with full amnesty was a major success and transformed cartel detection. ${ }^{72}$ The DOJ first provided leniency in 1995 for the lysine cartel. ${ }^{73}$ As a result of the information that emerged from the leniency program, cartel members settled with the DOJ in 1996 for criminal fines of $\$ 105$ million, which was a record amount at that time. ${ }^{74}$ Additionally, cartel members paid out $\$ 305$ million in private damages. ${ }^{75}$ Of note, the majority of lysine cartel members were international. ${ }^{76}$ This change in the make-up of cartel members by U.S. versus international members was significant. Prior to 1995 , fewer than $1 \%$ of all DOJ cartel indictments involved non-U.S. firms. ${ }^{77}$ Leniency helped to uncover more international cartels as additional international cartel cases quickly followed lysine. ${ }^{78}$

Following lysine, a change that began under Clinton and continues to the present day has been the increased internationalization of cartel prosecution. The

64. Until the implementation of the Sentencing Guidelines, judges were reluctant to impose significant sentences on white collar offenders. Sokol, supra note 4, at 795.

65. Ghosal \& Sokol, supra note 13, at S57.

66. Id.

67. Id.

68. Id.

69. Id.

70. Id.

71. Id.

72. Christopher R. Leslie, Replicating the Success of Antitrust Amnesty, 90 TEX. L. REV. 171, 172 (2012).

73. Ghosal \& Sokol, supra note 13, at S57.

74. Id. 1996 also marked the first use of the alternative fine statute (18 U.S.C. $§ 3571$ (d) (2018)).

75. CONNOR, supra note 52, at 448-55.

76. Ghosal \& Sokol, supra note 13, at S57.

77. Id. at $\mathrm{S} 57-58$.

78. As ICPAC (2000 at chapter 4) noted, the change in international priorities and the effect of new leniency were significant within a short time span. "From 1987 through 1990, the Antitrust Division did not file a single criminal cartel case against a foreign-based corporation or individual. . . By 1997, the figures had surged so that 32 percent of corporate defendants and the same number of individual defendants were foreign-based." InT'L COMPETITION POLICY AdVISORY COMM. TO THE ATT'y GEN. \& ASSISTANT ATT'y GEN. FOR ANTITRUST, FINAL REPORT 167 n.16 (2000). 
DOJ has increased the scope and depth of its cooperation with foreign enforcers on international cartels including coordinated enforcement and information exchange. ${ }^{79}$ As current head of the DOJ Antitrust Division, Makan Delrahim explains, "[w]ithout such close cooperation in criminal enforcement, I firmly believe that our most important prosecutorial tool, our leniency program, would be much less effective in uncovering some of the most harmful cartels." $\$ 0$

The George W. Bush presidency also introduced changes to the structure of cartel prosecutions. Congress passed the Antitrust Criminal Penalty Enhancement and Reform Act ("ACPERA") in 2004. ${ }^{81}$ The Act increased the maximum fine for collusion to $\$ 100$ million. ${ }^{82}$ It increased prison terms up to ten years and increased individual fines to $\$ 1$ million. ${ }^{83}$ The Act also offered single damages (unlike the usual treble damages) for the leniency applicant to cooperate with plaintiffs. ${ }^{84}$ Further, in 2006, Congress amended the wiretapping statute to include coverage of antitrust violations. ${ }^{85}$ Finally, in 2012, the DOJ closed its Atlanta, Philadelphia, and Cleveland field offices. ${ }^{86}$ DOJ Antitrust Division field offices historically participated in cartel enforcement, often in smaller cases. ${ }^{87}$ At the very end of the Bush administration, the DOJ published guidance of Frequently Asked Questions about the Antitrust Division's Leniency Program and Model Leniency Letters ${ }^{88}$ that addressed requirements for leniency, the application process, and its operation.

Under the Obama administration, changes came relating to individual culpability within organizations as a result of the Yates memo, ${ }^{89}$ which were immediately embraced by the DOJ Antitrust Division. ${ }^{90}$ Individual culpability became a priority within organizations as a result. ${ }^{91}$ Another change was under a small, highly particularized set of circumstances; the DOJ offered compliance credit as

79. Id. at 164 .

80. Makan Delrahim, Assistant Att'y Gen., Dep't of Justice, Antitrust Div., Remarks at the College of Europe in Brussels (Feb. 21, 2018).

81. Ghosal \& Sokol, supra note 13 , at S58.

82. $I d$.

83. Id.

84. Id.

85. Id.

86. Id.

87. $I d$.

88. See generally U.S. DeP'T OF JUST., FreQuently ASKEd Questions ABout the ANTITRUST Division's LENIENCY PROGRAM AND MODEL LENIENCY LeTters (2017), https:/www.justice.gov/atr/page/ file/926521/download.

89. Memorandum from Sally Quillian Yates, Deputy Attorney Gen., Dep't of Justice, to all U.S. Attorneys (Sept. 9, 2015), https://www.justice.gov/dag/file/769036/download.

90. Bill Baer, Assistant Attorney Gen., Antitrust Div., U.S. Dep't of Justice, Prosecuting Antitrust Crimes, Remarks as Prepared for the Georgetown University Law Center Global Antitrust Enforcement Symposium 8 (Sept. 10, 2014), https://www.justice.gov/atr/file/517741/download; Brent Snyder, Deputy Assistant Attorney Gen., Antitrust Div., U.S. Dep't of Justice, Individual Accountability for Antitrust Crimes, Remarks as Prepared for the Yale School of Management Global Antitrust Enforcement Conference 2 (Feb. 19, 2016), https:// www.justice.gov/opa/file/826721/download.

91. See sources cited supra note 90. 
a mitigating factor for lower penalties for companies involved in collusion. ${ }^{92}$ Corporate monitors for particularly egregious cartel violators were also introduced as an additional punishment beyond traditional fines and jail time. ${ }^{93}$

Finally, under the Trump administration, the Frequently Asked Questions about the Antitrust Division's Leniency Program and Model Leniency Letters ${ }^{94}$ were updated to reflect penalties, anonymous markers, related nonantitrust offenses (e.g., bribery), Type B leniency for employees, and protections for former employees. ${ }^{95}$ More recently, DOJ announced a newly formed Procurement Collusion Strike Force to address collusion in government procurement. ${ }^{96}$

These changes over time suggest several tentative conclusions. U.S. cartel enforcement and prosecutions have undergone dramatic fluctuations over the last four to five decades. Unlike other parts of antitrust that went through significant policy transformation since the law was misguided because it was not in sync with developments in economic analysis, the emphasis on cartel prosecution and substantive law of prosecution of cartels was economically correct, but the mechanism of prosecution needed to be reformed.

\section{DATA DESCRIPTION AND INTERTEMPORAL PATTERNS}

Following up on the narrative in the previous Parts, we now provide a quantitative look at the transformation of U.S. cartel enforcement by examining the intertemporal path of some of the key cartel prosecution and enforcement data over a long time period, 1969-2016. Subsequently, in Part V, we use this data to empirically estimate some relationships to highlight the effects of various policy and institutional shifts.

\section{A. Data Sources}

Our primary source of data is the DOJ's Antitrust Division Workload Statistics for the period 1969-2016. ${ }^{97}$ The earliest date for which we have all the data is 1969 , and the most recent year for which data are available is $2016 .^{98}$ This provides us with forty-eight years of time-series data on enforcement and related attributes. Data for the more recent years are available online, and for

\footnotetext{
92. D. Daniel Sokol, Troubled Waters Between U.S. and European Antitrust, 115 MICH. L. REV. 955, 974 (2017).

93. See Sokol, Troubled Waters, supra note 92.

94. U.S. DEP'T OF JUSTICE., Frequently Asked Questions, supra note 88.

95. See generally id.

96. Justice Department Announces Procurement Collusion Strike Force: a Coordinated National Response to Combat Antitrust Crimes and Related Schemes in Government Procurement, Grant and Program Funding, U.S. DEP'T OF JUSTICE, https://www.justice.gov/opa/pr/justice-department-announces-procurementcollusion-strike-force-coordinated-national-response. The DOJ Antitrust Division has taken interest in compliance programs. See Makan Delrahim, Assistant Attorney Gen., Dep't of Justice, Wind of Change: A New Model for Incentivizing Antitrust Compliance Programs (July 11, 2019), https://www.justice.gov/opa/speech/assistantattorney-general-makan-delrahim-delivers-remarks-new-york-university-school-1-0.

97. Division Operations, U.S. DEP'T OF JUSTICE, https://www.justice.gov/atr/division-operations (last updated July 1, 2019).

98. Id.
} 
the earlier years we compiled the data from the Antitrust Division's published paper records.

The specific annual data series we examine include the total number of antitrust cases; the total number of civil and cartel cases; various penalties related to cartel cases such as the number of individuals incarcerated and the number of days served in jail; and monetary fines levied on individuals and corporations. ${ }^{99}$ There are some nuances about the Antitrust Division's workload statistics on cartel cases that are important to clarify. First, the time series on cartel cases relates to the number of cases filed during the year as opposed to the actual number of cartels prosecuted. Second, the DOJ's official statistics are for the fiscal reporting year as opposed to the calendar year. These two aspects imply that the annual data on cartels need to be interpreted carefully. The additional aspects of the DOJ's cartel data are as follows: the DOJ's average win-loss record on cartels is near perfect, ranging from $98 \%$ to $100 \%$ for most years. ${ }^{100}$ This implies that (a) cartel cases filed nearly always lead to prosecution; and (b) the typical time from initiating a cartel case to prosecution appears to be about one and a half years. $^{101}$

Given the data characteristics and limitations noted above, the data on cartel cases are used to effectively proxy the data on cartels prosecuted. But the data on the number of firms and individuals prosecuted, and fines, are the actual series. Therefore, for a given year, this may create a mismatch between the number of cartels prosecuted versus the various prosecutions and penalties data. If a cartel case is decided quickly then there is no mismatch, but if a cartel case is decided over a longer duration, this is likely to be a mismatch.

In contrast to the cartel case time-series, the data on incarceration, fines on individuals, and fines on corporations are based on actual prosecutions during the year. ${ }^{102}$ The summary statistics on the fines per cartel and the fines per firm, along with the data on the number of firms convicted per cartel, need to be interpreted accordingly. Given the nature of the statistics as maintained by the DOJ, there is no easy way to resolve this issue. Given that our primary objective is to focus on the medium to long term patterns and not the short-run fluctuations, however, this attribute of the time-series data may not matter much. Overall, while these administrative and definitional aspects will not alter the long-run relationships we wish to study, it is important to keep these in mind as we discuss the data and the estimates.

While our data enables us to examine the shorter-run, year-to-year fluctuations in various enforcement variables, our primary focus is on the more systemic changes under alternative policy regimes and presidential periods. The fundamental effects we are focusing on essentially play out over the medium-to-longer run. Given the characteristics of the DOJ's cartel cases data noted above, the

99. Id.

100. Id.

101. Ghosal, The Genesis of Cartel Investigations, supra note 17, at 86.

102. See, e.g., U.S. DeP'T OF Just., AnTitrust Division WorklOAD Statistics FY 2009-2018 11, https://www.justice.gov/atr/file/788426/download. 
broad time-series patterns and shifts over time on cartel cases initiated, for all practical purposes, will mimic the actual time-series on cartel prosecutions. Given this, we refer to the cartel case series as the cartel prosecutions series.

Aside from the antitrust enforcement data, we also use some U.S. macroeconomic data, such as U.S. GDP. These data are from the Federal Reserve Bank of St. Louis. ${ }^{103}$ Finally, we use data on the total number of mergers and acquisitions in the U.S. economy. These data are compiled from various sources including the U.S. Federal Trade Commission merger series, Thompson's Financials, and the Institute for Mergers, Acquisitions and Alliances. ${ }^{104}$ All monetary data in our paper are measured in real 2010 dollars. In Table 1 we present the summary statistics for some of the key enforcement and prosecution indicators.

TABLE 1: SUMMARY STATISTICS

\begin{tabular}{|l|l|l|}
\hline Variable & Mean & Std. Deviation \\
\hline Total cartel cases per year & 44.52 & 23.71 \\
\hline Total fines per year (2010\$, '000) & $264,940.62$ & $405,456.32$ \\
\hline Total jail days per year & $6,101.32$ & $7,976.23$ \\
\hline Fines per cartel (2010\$, '000) & $7,068.64$ & $10,763.38$ \\
\hline Jail days per cartel & 164.05 & 248.05 \\
\hline Number of individuals fined per cartel & 1.22 & 1.52 \\
\hline Number of firms fined per cartel & 1.81 & 2.66 \\
\hline
\end{tabular}

\section{B. Intertemporal Patterns of Cartel Enforcement}

Next we display several of our main variables in Figures 1-8 and discuss the patterns, keeping in mind that our data cover the period 1969-2016. Figure 1 shows that prior to $1979-1980$, the mean number of cartel cases was about twenty per year. The mean number rises sharply during the Reagan years to about sixty cases per year. Thereafter, it falls steadily reaching a low of twenty-five to thirty cases per year during the George $\mathrm{W}$. Bush administration. The mean rate of cartels prosecuted during the George W. Bush administration was almost at historical lows, harking back to the late 1960s and early 1970s. This is particularly revealing as our general understanding from the shift during the Reagan years was that enforcement importantly moved away from civil toward cartel enforcement. ${ }^{105}$ But the starkly low numbers during the Bush administration show a reversal and highlight the sharp variation within Republican administrations' variation in cartel enforcement. The high mean rate of cartel prosecutions is effectively offset by the historic low mean during the George W. Bush presidency.

103. Gross Domestic Product, Fed. Res. BAnK OF St. Louis: FRED Economic Data (Aug. 29, 2019), https://fred.stlouisfed.org/series/GDP.

104. Data Sets, FeD. TRADE COMmission, https://www.ftc.gov/site-information/open-government/datasets (last visited Jan. 20, 2020); M\&A Statistics, InST. MERGERS, ACQUISITIONS, \& ALLIANCES, https://imaainstitute.org/mergers-and-acquisitions-statistics (last visited Jan. 20, 2020).

105. Vivek Ghosal, Regime Shift in Antitrust Laws, Economics and Enforcement, 7 J. COMPETITION L. \& ECON. 733, 771 (2011). 
Intriguingly, however, Figure 1 shows a sharp increase in the mean number of cartels prosecuted during the Obama administration. While the pre-1980 period generally contains uniformly low numbers of prosecutions, the post-1980 period reveals a mixed picture with highs reaching almost 100 cases and lows of about twenty-five. These patterns are important to highlight as the key leniency change occurred in 1993 with subsequent changes in penalties, which lead to a more effective detection and enforcement mechanism. If it were the case that there was a reduction in the (unmeasured) population of cartels due to the improved leniency mechanism, it would be somewhat unlikely that there would be a sharp increase subsequently during the Obama administration. Perhaps a conclusion one may reach is that the Bush administrations' stance was hands-off markets, irrespective of the nature of the violations, civil or cartel, which is a different stance from the Reagan administration, which altered the ratio with less civil and more cartel prosecutions.

Figure 1: U.S. ANTITRUst CASES: Total, Civil, AND CARTEL

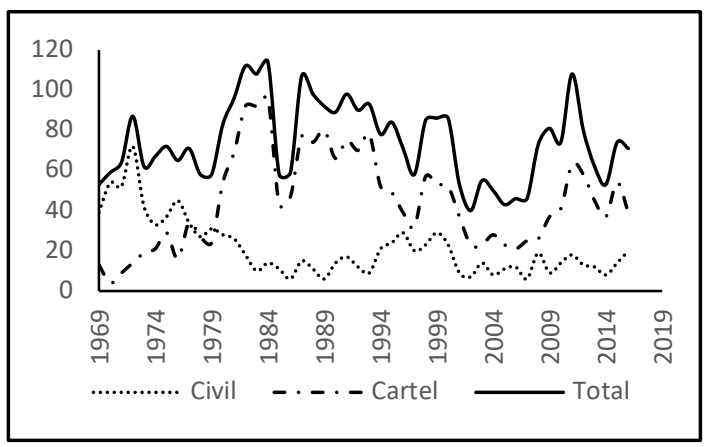

Figure 1 also allows us to put the cartel prosecutions in perspective relative to the Antitrust Division's civil enforcement as well as the total. Aside from the Clinton administration, U.S. civil enforcement shows a dramatic decline. This is consistent with the Chicago School's emphasis on efficiencies in, for example, both horizontal and vertical mergers as well as conduct. ${ }^{106}$

While in this Article we do not conduct extensive econometric tests of structural breaks (regime shifts) in the time-series data due to our desire to reach a wider interdisciplinary audience, we draw on the estimation and inferences in an earlier paper to emphasize some of the results. In a prior article, Ghosal shows that the estimated structural break for cartel cases was 1979 and for civil cases 1972. ${ }^{107}$ The estimation and testing for structural breaks showed that the sample mean of the cartel cases series was statistically higher post-1979, and the sample mean of the civil cases was statistically lower post-1972. ${ }^{108}$ One complication in implementing the structural break tests is the econometric methods were developed for high-frequency data with long time-series. Such data allow for more 
sophisticated testing for "multiple" structural breaks in the data, when present. Our data are annual and for a total of forty-eight years. In terms of the received econometrics literature for testing for structural breaks, this is not a large enough time-series to test for multiple breaks. ${ }^{109}$

To present a clearer picture on the greater emphasis on cartel enforcement, in Figure 2 we present the ratio of cartel cases and civil cases to total antitrust cases. The pre-Reagan years saw the ratio at about $30 \%$ on average. This ratio increases to an average of over $70 \%$ during the Reagan years. The ratio declines steadily after that, reaching a low of $36 \%$ during the George W. Bush administration, before rising again under the Obama administration. While the mean ratio (as well as the actual number of cartels prosecuted) clearly seems to vary between presidential administrations, there is also substantial variation within presidential administrations. ${ }^{110}$ In comparison, we see that the ratio of civil cases to total cases steadily declines through the 1970s reaching a low of around $10 \%$ in the early 1980 s. Subsequently, the mean ratio stabilizes in the approximately $20 \%$ range.

Figure 2: Ratio of CARTEl ANd Civil to Total Antitrust Cases

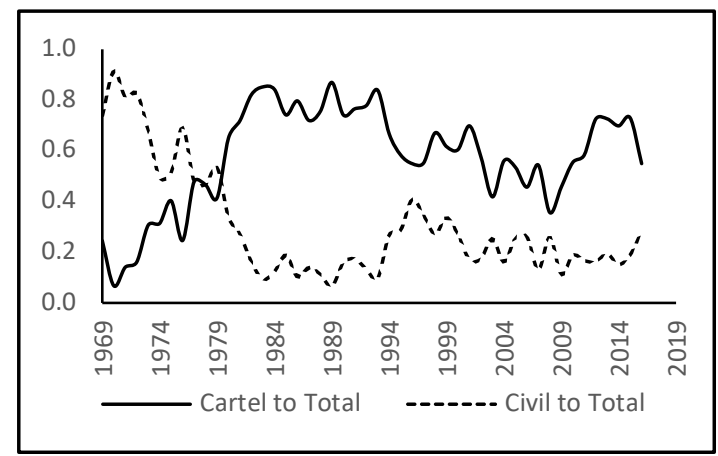

109. See, e.g., George Kapetanios, Unit Root Testing Against the Alternative Hypothesis of up to $m$ Structural Breaks, 26 J. TIME SERIES AnAlysis 123, 131 (2005); Zhongjun Qu \& Pierre Perron, Estimating and Testing Structural Changes in Multivariate Regressions, 75 ECONOMETRICA 459, 492 (2007).

110. While we do not display these data in a figure, ratio of total cartel cases to total civil cases is less than 1.0 in the pre-1980 period, a mean ratio of about six during the 1980-1993 period, and thereafter fluctuates around a mean of about 2.4 . 
FIGURE 3: TOTAL NUMBER OF CORPORATIONS AND INDIVIDUALS FinED

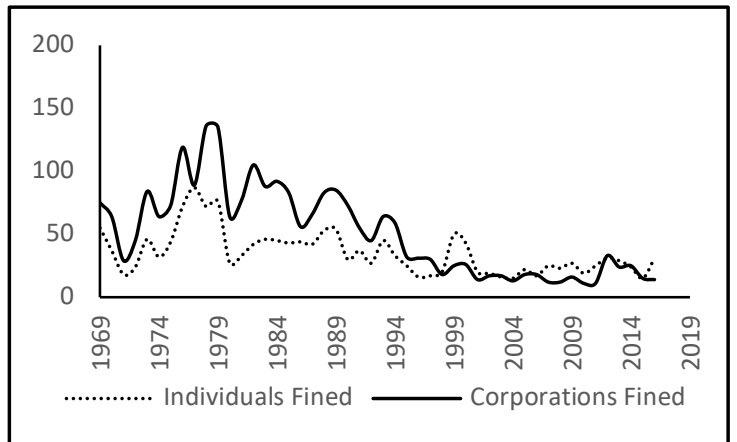

After having examined the overall number of cartel cases, we now focus on penalties related to cartel prosecutions. First, we examine incarceration time. Incarceration time is only one aspect of penalty and is unique to U.S. antitrust. The European Commission, among other important jurisdictions, does not have jail terms for cartel offenders. ${ }^{111}$ Figure 3 shows that the number of individuals and corporations fined have steadily declined over time. At face value, this presents a puzzling picture as it may be interpreted as relatively weaker enforcement. The real story, however, is revealed in the subsequent figures.

Figure 4 shows that the average number of days of incarceration has risen dramatically. The initial part of the sample shows an average of about 100 days of incarceration, but this number rises to almost 700 days of incarceration on average in the following part of the sample. These data show a completely different pattern compared to the data on total cartels prosecuted. The incarceration related penalties are clearly a product of the policy changes we documented earlier. ${ }^{112}$ Irrespective of whether actual number of cartels prosecuted were high or low, the penalty regime moved to a new, higher plane.

Figure 4: AVERAGE NUMBER OF DAYS INCARCERATION

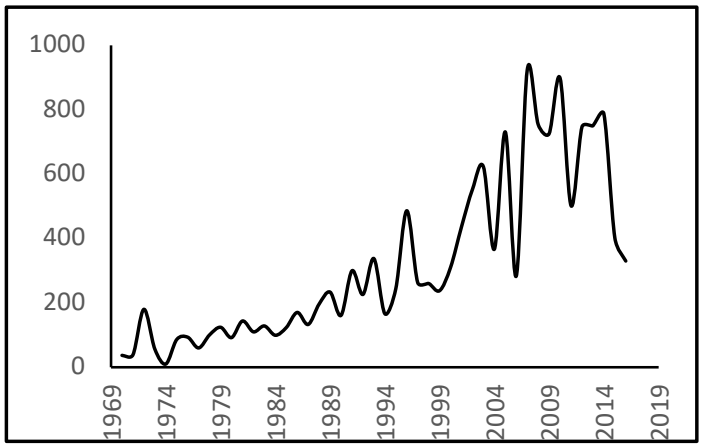

111. John M. Connor, Global Antitrust Prosecutions of Modern International Cartels, 4 J. INDUS. Competition \& TRADE 239, 248 (2004); Francesco Ducci, Cartel Criminalization in Europe: Addressing Deterrence and Institutional Challenges, 51 VAND. J. TRANSNAT'L L. 1, 3 (2018).

112. See supra Part III. 
Further detail is added in Figure 5, which displays the total number of individuals sentenced to incarceration. These data show a lot more fluctuation and less of a secular trend (as is the case in Figure 4). There is no definitive shift in the number of individuals sentenced to incarceration. The total number of individuals incarcerated increases dramatically during the Reagan administration, then falls to relatively low levels, before showing an uptick at the end of the sample. Overall, and examining the average number of days of incarceration in Figure 4, the clear message is the severity of penalties has increased dramatically over time.

Figure 5: TOtal NumBer of INDIVIDUALS SENTENCED TO INCARCERATION

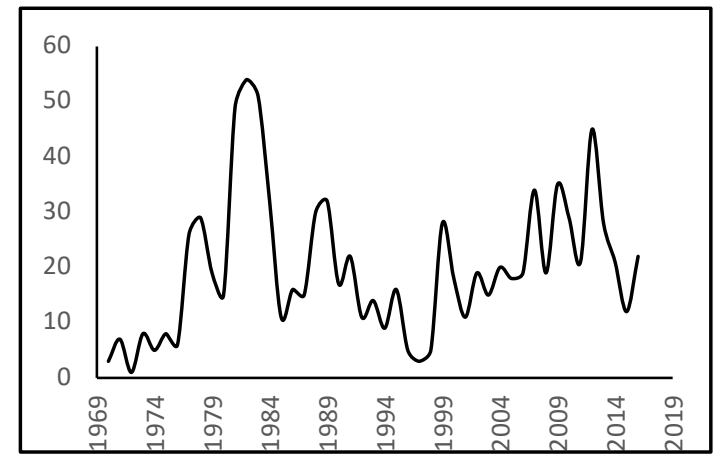

FIGURE 6: TOTAL INDIVIDUAL AND CORPORATE FINES

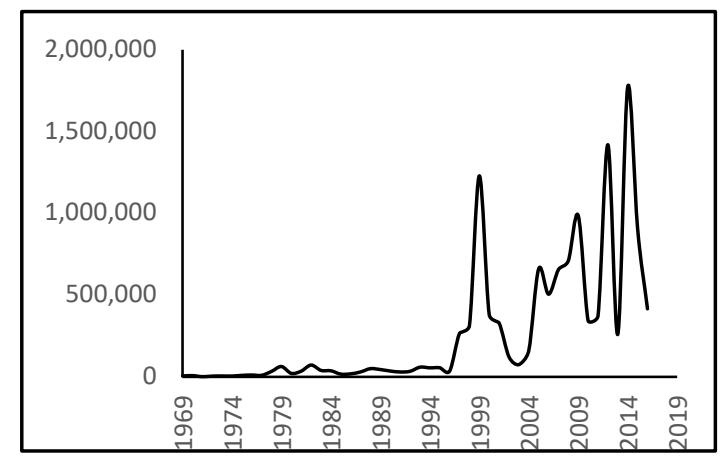

Next we focus on the second aspect of penalties, monetary fines. We examine total fines as well as fines on individuals and corporations. Figures 6 reveals that there has been an order of magnitude increase in total fines levied on individuals and corporations after the mid-1990s. In Figure 7 and Figure 8 we disaggregate the data and display fines per individual and fines per corporation. The fines per individual show a lot of variation over time, but lack of a clear secular trend. There are some large spikes in the period mid-1990s to mid-2000s, but aside from these peaks, there emerges no clear secular trend. The data on corporate fines in Figure 8, however, show that before mid-1900s the fines were extremely low but have large increases after that. The mid-1990s also correspond 
to the period when the leniency program was restructured. The figures suggest that introduction of the revised leniency program created increased effectiveness for cartel enforcement (detection) and penalties.

Figure 7: Fine PER INDIVIDUAL (REAL 2010\$, '000)

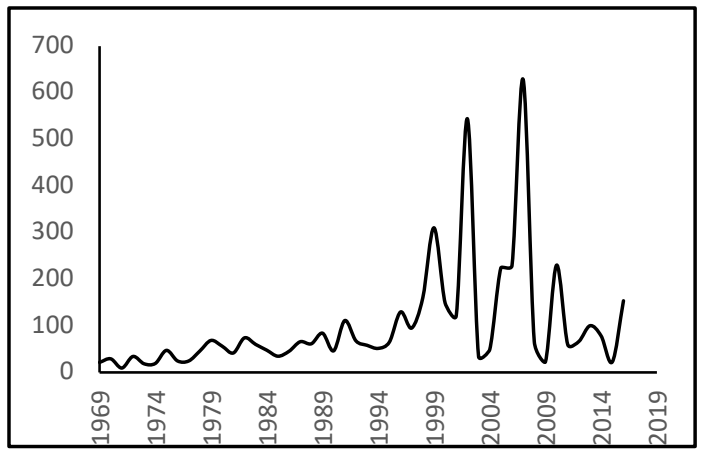

FiguRe 8: Fine PER CORPORATION (REAL 2010\$, ’000)

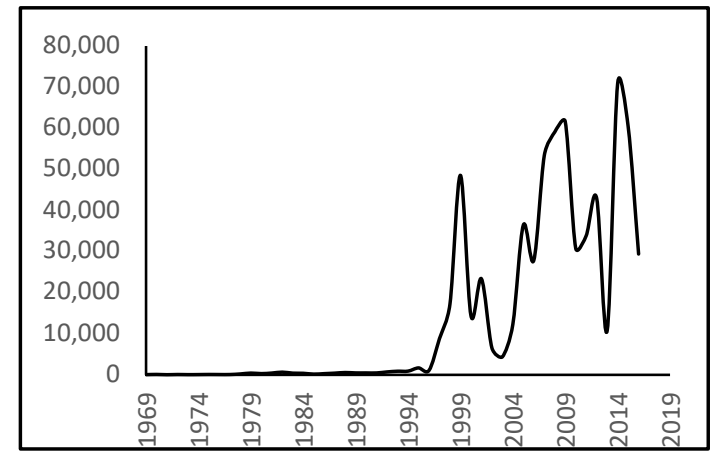

Overall, the story that emerges for U.S. cartel enforcement from Figures 18 is that the main changes in enforcement appear to be fewer in the number of cartels, individuals, and corporations prosecuted, but more in the increasing severity of penalties in terms of incarceration time and fines.

Finally, we examine two data series related to total funding for the Antitrust Division, and the ratio of cartel fines to the Antitrust Division's funding. The total funding (budget) data (real 2010 dollars) in Figure 9 shows a marked decrease during the Reagan administration, then a secular increase over several years, and relatively flat levels since the 2003-2004 period. Figure 10 shows that the "ratio" of total cartel fines to the Antitrust Division's budget averages around 0.4 before the 1995-1996 period. After that, however, the mean value of the ratio is close to five, with highs reaching values as large as ten to twelve. This large increase since the mid-1990s is, of course, due to the large increase in individual and corporate fines we discussed in Figures 7-8. ${ }^{113}$

113. See supra Section IV.B. 
Figure 9: ANTITRUST Division Funding (REAL 2010\$, '000)

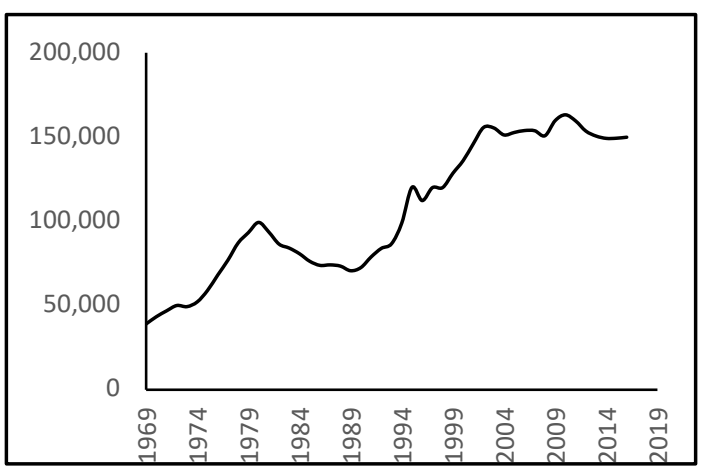

FIGURE 10: CARTEL FINES TO ANTITRUST DIVISION FUNDING

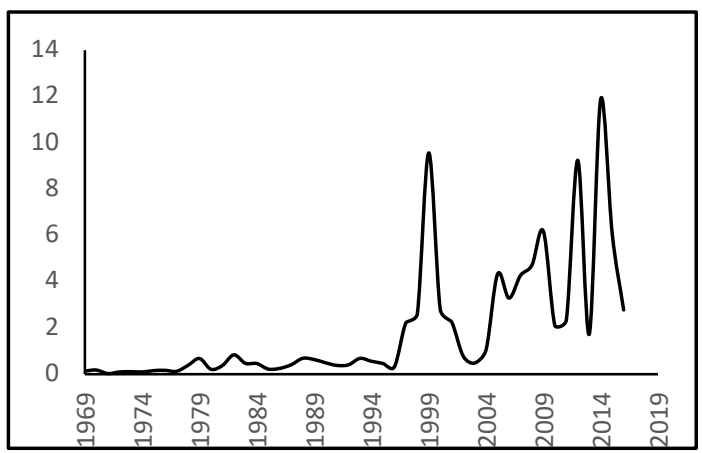

\section{EMPIRICAL FRAMEWORK AND ESTIMATION RESULTS}

Having examined the broad patterns in the data, we now turn to estimating the effects of various forces driving cartel prosecutions and penalties. In Section V.A we spell out the empirical specification. Given our desire to reach an interdisciplinary audience, we restrict our framework and scope of analysis only to the essentials. After discussing the empirical specification, we present our estimation results in Section V.B.

\section{A. Empirical Framework}

In this Section, we develop the empirical specification to examine whether the institutional changes related to leniency and the new penalty programs, among other factors we consider below, had measurable effects on the full array of cartel enforcement and prosecution variables. Over our full sample period from 1969-2016, the number of cartel cases prosecuted by the DOJ has perhaps been the most visible enforcement variable. As we noted in Part IV, the fines, for example, show noteworthy jumps only at the end of our sample period. ${ }^{114}$ Given

114. See supra Part IV. 
this, we structure our specification by focusing on the cases prosecuted, and then discuss estimation for monetary fines and incarceration days.

There are multiple forces that are likely to influence the DOJ's cartel enforcement path. In our empirical specification, we conclude a wide range of variables are likely to affect the DOJ's decisions and enforcement. The total population of cartels is, of course, unobservable, and can only be modeled as a function of variables we can measure. In our empirical specification, we include the following:

(1) Institutional factors ("Inst"). Several administrative and legal milestones have affected cartel enforcement. It is widely recognized by antitrust scholars and the DOJ that the old leniency program started in 1978 was ineffective. ${ }^{115}$ The leniency program became effective when the DOJ restructured it and the new program went into effect in 1993, with the first leniency settlements in 1996 (Lysine case). ${ }^{116}$ Given this, we focus on the 1993 date. We focus on two other institutional innovations: The Antitrust Amendments Act (1990) which increased fines and jail terms; and ACPERA (2004), which further increased fines and jail terms. ${ }^{117}$ With the introduction of Inst features like leniency, high fines and incarcerations regime, we expect higher likelihood of detection and deterrence and less collusion.

(2) Political factors ("Pres"). Examining the potential presidential effect is interesting because of the institutional structure of the Antitrust Division. The Assistant Attorney General, who heads the Antitrust Division, is appointed by the U.S. President, potentially setting the stage for shifts in enforcement with changes in the President and their specific priorities. ${ }^{118}$ If a presidential regime is such that it is placing greater emphasis on cartel enforcement, detection, and prosecution, we expect collusion to be lower due to the increased likelihood of detection and penalties.

(3) DOJ's investigative workload (“Busy"). First, periods of high M\&A activity may swamp the Antitrust Division with merger clearance and investigation work, potentially taking resources away from cartel enforcement. Second, in selected instances, examination of merger-specific information during routine investigations may serve as one of the conduits for information about collusive

115. Joe Chen \& Joseph E. Harrington, Jr., The Impact of the Corporate Leniency Program on Cartel Formation and the Cartel Price Path, in The Political EConomy of AnTITRUst (Vivek Ghosal \& Johan Stennek eds., 2006); Hammond, supra note 56.

116. While these factors have transformed cartel enforcement, in the bigger picture these changes can be viewed as endogenous to broader shifts in intellectual thinking about cartel enforcement and the political willingness to prosecute. Robert W. Crandall \& Clifford Winston, Does Antitrust Policy Improve Consumer Welfare? Assessing the Evidence, 17 J. ECON. PERSP. 3, 14-15 (2003); Kovacic \& Shapiro, supra note 5, at 56.

117. Antitrust Criminal Penalty Enhancement and Reform Act of 2004, Pub. L. No. 108-237, 118 Stat. 661 (2004); Antitrust Amendments Act of 1990, Pub. L. No. 101-588, 104 Stat. 2879 (1990).

118. The number of cartel cases in the post-WWII period was approximately twenty per year through the Carter years. Prosecutions increased by $112 \%$ during the Reagan administration, and the upswing continued during the George H.W. Bush administration. Since then, the number of cartel cases has tapered off, followed by a marked reduction of prosecutions under the George W. Bush administration. There was an uptick during the Obama administration. Ghosal \& Sokol, Policy Innovations, supra note 11, at 418. 
activity in markets (Ghosal, 2008 and 2011a). ${ }^{119}$ We use the total number of antitrust investigations by the Antitrust Division as our proxy for Busy.

(4) Macroeconomic conditions ("Cycle"). Examining the effects of business cycles on cartel activity is common in the literature. ${ }^{120}$ The main argument regarding Cycle is that we expect the propensity to engage in collusion to be higher when economic conditions are weak due to the relationship to low demand. ${ }^{121}$ Our main control variable is the percentage change in GDP.

(5) DOJ's funding ("Funds"). An increase in the DOJ's funding is a useful control as greater investigative resources signals potentially more vigorous enforcement. Since this is a relatively transparent signal, it has the potentially to influence firms' behavior toward fewer anti-competitive activities. The previous empirical literature, however, indicates that the link between funding and cartel cases appears rather tenuous, with no clear estimated effect of funding on actual enforcement patterns. ${ }^{122}$ We use the percentage change in real funding as the control variable. ${ }^{123}$

Combining the above variables, our specification is given by (1):

$$
\begin{aligned}
{[1] \text { Cases }_{t}=} & \alpha_{0} \\
& +\sum_{k=1}^{n}\left[\delta_{k} \text { Cases }_{t-k}+\varphi_{k} \text { Busy }_{t-k}+\tau_{k} \text { Cycle }_{t-k}\right. \\
& \left.+\lambda_{k} \text { Fund }_{t-k}\right]+ \text { Inst }_{t}+\phi \text { Pres }_{t}+\omega_{t} .
\end{aligned}
$$

Specification (1) captures the dynamic path of cartel prosecutions. In our estimation in Section V.B, we also use other dependent variables such as those related to monetary fines and jail terms.

119. Ghosal, The Genesis of Cartel Investigations, supra note 17, at 63

120. See Ghosal \& Sokol, Policy Innovations, supra note 11, at 418.

121. See, e.g., Dick, supra note 13, at 244-45; Ghosal, Regime Shift, supra note 105, at 744-45; Ghosal, The Genesis of Cartel Investigations, supra note 17, at 72-73; Levenstein \& Suslow, supra note 13, at 74-75.

122. The picture related to funding is complicated for various reasons. First, the Antitrust Division can "utilize" existing staff (attorneys, paralegals, economists, etc.) at varying rates over workload cycles. When workload is high (low), the staff work more (less), at a higher (lower) rate of utilization. Second, the Antitrust Division has the ability to access additional funding for cases they are actively prosecuting, and under litigation. Third, the exact nature of enforcement, cases being pursued, and related attributes, can change under low versus high funding periods. For example, under Reagan, funding dropped sharply, but so did civil enforcement priorities. These are some of the reasons why the literature has had a difficult time precisely estimating the effect of funding on enforcement actions. For a discussion of related issues, see generally Ghosal, Regime Shift, supra note 105, at $751-53$.

123. The level of funding is influenced by a combination of factors related to the complexity of cases, number of internal investigations, party of the President, composition of the House and the Senate, among others. In addition, the utilization of economists and attorneys (whose salaries are the most significant component of the Antitrust Division's annual budget) vary considerably over work cycles. This variation in utilization poses a problem of clearly linking antitrust investigations to the level of funding. Further, since the Antitrust Division has to request funds from the legislature and requests for increase in funds may follow increase in investigations, funding may potentially be endogenous. Vivek Ghosal \& Joseph Gallo, The Cyclical Behavior of the Department of Justice's Antitrust Enforcement Activity, 19 INT'L J. INDUS. ORG. 27, 42-43 (2001). Ghosal and Gallo also found no evidence in the data that funds are endogenous. See id. 


\section{B. Estimation Results}

The estimation results are presented in Table 2 . The main inferences are as follows:

TABLE 2: U.S. CARTEL PROSECUTIONS AND PENALTIES

\begin{tabular}{|l|l|l|l|l|l|l|}
\hline & $\begin{array}{l}1 . \text { Total } \\
\text { cartel cases }\end{array}$ & $\begin{array}{l}2 . \text { Total } \\
\text { fines per } \\
\text { cartel }\end{array}$ & $\begin{array}{l}\text { 3. Total jail } \\
\text { days per } \\
\text { cartel }\end{array}$ & $\begin{array}{l}\text { 4. Number } \\
\text { of } \\
\text { individuals } \\
\text { jailed per } \\
\text { cartel }\end{array}$ & $\begin{array}{l}\text { 5. Number } \\
\text { of } \\
\text { individuals } \\
\text { fined per } \\
\text { cartel }\end{array}$ & $\begin{array}{l}\text { 6. Number } \\
\text { of firms } \\
\text { fined per } \\
\text { cartel }\end{array}$ \\
\hline Intercept & $\begin{array}{l}41.552^{* *} \\
(0.037)\end{array}$ & $\begin{array}{l}-3.825 \\
(0.629)\end{array}$ & $\begin{array}{l}-377.195 \\
(0.144)\end{array}$ & $\begin{array}{l}-0.156 \\
(0.609)\end{array}$ & $\begin{array}{l}1.743^{*} \\
(0.060)\end{array}$ & $\begin{array}{l}2.536 \\
(0.130)\end{array}$ \\
\hline LDV & $0.472^{* * *}$ & -0.057 & 0.133 & $0.255^{* *}$ & -0.002 & -0.067 \\
& $(0.010)$ & $(0.773)$ & $(0.473)$ & $(0.050)$ & $(0.980)$ & $(0.471)$ \\
\hline Policy2 & $13.905^{*}$ & 0.712 & $187.035^{*}$ & 0.221 & $-1.079^{*}$ & -1.467 \\
& $(0.093)$ & $(0.809)$ & $(0.078)$ & $(0.241)$ & $(0.088)$ & $(0.197)$ \\
\hline Policy3 & -1.522 & $7.502^{* *}$ & $325.323^{* *}$ & 0.165 & $-1.626^{* * *}$ & $-3.041^{* * *}$ \\
& $(0.837)$ & $(0.047)$ & $(0.030)$ & $(0.388)$ & $(0.009)$ & $(0.009)$ \\
\hline Policy4 & -8.356 & $14.934^{* * *}$ & 255.466 & $0.377^{* * *}$ & $0.406^{*}$ & 0.590 \\
& $(0.286)$ & $(0.006)$ & $(0.110)$ & $(0.003)$ & $(0.100)$ & $(0.153)$ \\
\hline President & $-8.489 * *$ & 0.147 & 171.912 & 0.096 & -0.132 & -0.358 \\
& $(0.037)$ & $(0.962)$ & $(0.119)$ & $(0.314)$ & $(0.418)$ & $(0.216)$ \\
\hline Busyt-1 & -0.030 & 0.013 & $0.593^{*}$ & 0.001 & 0.000 & 0.003 \\
& $(0.350)$ & $(0.193)$ & $(0.071)$ & $(0.246)$ & $(0.709)$ & $(0.281)$ \\
\hline GDPt-1 & -1.493 & 0.174 & -16.069 & -0.010 & 0.054 & 0.064 \\
& $(0.173)$ & $(0.635)$ & $(0.157)$ & $(0.485)$ & $(0.244)$ & $(0.451)$ \\
\hline Fundst-1 & -0.484 & $-0.317 *$ & 3.287 & 0.008 & $0.039^{*}$ & $0.062 *$ \\
& $(0.132)$ & $(0.091)$ & $(0.440)$ & $(0.193)$ & $(0.065)$ & $(0.067)$ \\
\hline $\bar{R}^{2}$ & 0.668 & 0.521 & 0.386 & 0.297 & 0.479 & 0.548 \\
\hline$\rho$ & -0.160 & -0.125 & -0.237 & -0.099 & -0.039 & -0.243 \\
\hline
\end{tabular}

Notes:

1. All specifications are estimated using annual time-series, 1969-2016. $L D V$ is the lagged-dependent variable, and President is a dummy variable: Republican $=1$.

2. The various policy regime periods are as follows:

Policy1: $\leq 1977$. Pre-old leniency period. (This is excluded from the estimated regression as the effect is subsumed into the regression constant.)

Policy2: 1978-1992. Old leniency to new leniency period.

Policy3: 1993-2003. New leniency and Antitrust Amendments Act period.

Policy4: 2004-2013. Post-ACPERA period.

3. $\quad$-values computed from robust standard errors (two-tailed test) are in parentheses. A $p$-value $<0.001$ is reported as 0.001 . Asterisks *, **, and ** denote significance at the $10 \%, 5 \%$ and $1 \%$ levels, respectively. $\rho$ denotes the firstorder autocorrelation.

(1) The Policy variables (Policy2, Policy3, Policy4) are generally not significant for the total number of cartels prosecuted. ${ }^{124}$ But they are highly significant for the total fines per cartel and jail days per cartel. In general, they are not particularly meaningful for determining number of individuals jailed per cartel, or number of individuals and firms fined per cartel. Examining column 2 in Table 2 related to total fines per cartel, we see that the Policy3 (1993-2003: new leniency and the Antitrust Amendments Act period) and Policy4 (2004-2013: post-

124. We keep in mind that since there are four Policy variables, we include three in the estimated regression with Policy1 subsumed in the regression intercept term. 
ACPERA period) estimates are highly significant, with the Policy4 estimate being an order of magnitude larger than Policy3. For total jail days per cartel (column 3), we see that the Policy2 and Policy estimates are statically significant and quantitatively large. The Policy4 estimate is large, but the significance level is marginal, only at the $11 \%$ level. As with the fines effects in column 2, the incarceration effects in column 3 show large policy effects. These effects tally with our discussions in Parts I through III related the key institutional and policy changes and ratcheting up of monetary fines and incarceration days that can be imposed.

It is somewhat intriguing that the estimated effects of the Policy variables are generally statistically insignificant and quantitatively small for the three variables related to: the number of individuals jailed per cartel (column 4), the number of individuals fined per cartel (column 5), and the number of firms fined per cartel (column 6). A lot of the official and press coverage on busting cartels since the prosecution of the Lysine cartel has focused on how the DOJ has gone after large and expansive (in terms of firms and individuals colluding) international cartels. While this does show up in fines levied and jail terms (columns 2 and 3), it does not show up in the last three columns of Table 2.

(2) The political party of the President, with a simple Republican versus Democrat demarcation is only significant with a negative coefficient for total cartels prosecuted. The negative and significant estimate implies that over our full sample period from 1969-2016, somewhat fewer cartels were prosecuted under Republican administrations. This is perhaps not a finding one may expect a priori as one may expect, for example following the Reagan change in emphasis, that Republicans would prosecute more cartels. This negative sign is likely being driven by the very low, almost historically low, prosecutions under the George W. Bush administration. The presidential variable is not significant in any other column. We note that we cannot include each presidential period specifically in the estimated regression as the presidential terms have significant overlaps with the included Policy1 to Policy4 variables.

(3) In general, the variables Busy, GDP, and Funds are not significant. These findings are similar to those in some of the earlier literature. ${ }^{125}$ As we had noted earlier, the complexities of allocation and utilization of the Antitrust Division's professionals to alternative areas of enforcement, as well as varying utilization rates for staff over workload cycles, renders no clear predictions on those estimated coefficients. While some papers in the literature find that recessions lead to greater numbers of cartels prosecuted, there are other papers that find no relationship.

(4) The lagged dependent variable is significant only for total cartel cases (column 1) and number of individuals jailed per cartel (column 4), indicating persistence in these variables. The lagged dependent variable is not significant for any of the other variables.

125. Ghosal, Regime Shift, supra note 105, at 753-55; Ghosal \& Sokol, Policy Innovations, supra note 11, at $420-24$. 
We experimented with alternative specifications, including considering deeper lag lengths. Our results were similar in spirit. Our main conclusion from the above empirical exercise is that the policy shifts related to fines and incarcerations affected those variables considerably, but do not reveal a meaningful impact on total number of cartels prosecuted, or the number of individuals and corporations fined per cartel.

\section{VI. (Potential) Decline of CARTel Enforcement ANd Prosecutions?}

As we noted in Figure 1, with some fluctuations, the DOJ Antitrust Division is prosecuting fewer cartels. This has been the case for a number of years, aside from the increase under the Obama administration. Understanding the causal factors may be complicated and require additional research to disentangle a number of potential factors. Below we discuss some factors that may be at play driving the secular trends and intertemporal fluctuations.

\section{A. Leniency is a Success, There is More Internal Compliance, and There are Fewer Cartels}

From the enforcement standpoint, perhaps leniency is working and there may be fewer cartels being formed. ${ }^{126}$ Data analytics also may be leading to greater internal detection and monitoring. The theoretical literature on leniency is that such a program increases the costs of collusion. ${ }^{127}$ Thus, the more successful leniency has been, the more it has worked to reduce the total number of cartels by preventing formation as well as destabilizing existing cartels. ${ }^{128}$

Fewer cartels formed (and hence prosecuted) may be due to an increasingly strong overall enforcement structure not merely in the United States but in other major jurisdictions, particularly at the European level due to the work of DG Competition. ${ }^{129}$ Significant fines for fewer cartels on the part of DG Competition exceed those of the Antitrust Division significantly. ${ }^{130}$ Firms have responded with increased compliance training that identify and mitigate situations that lead

126. This could be true as a secular trend, but it does not explain the fairly sharp increase going from the Bush to Obama administrations. This signals more forces are at plan than just leniency and deterrence.

127. See Joseph E. Harrington, Jr. \& Myong-Hun Chang, When Can We Expect a Corporate Leniency Program to Result in Fewer Cartels?, 58 J.L. \& ECON. 417, 443 (2015).

128. See Massimo Motta \& Michele Polo, Leniency Programs and Cartel Prosecution, 21 INT’L J. INDUS. ORG. 347, 349 (2003). See generally Cécile Aubert et al., The Impact of Leniency and Whistle-Blowing Programs on Cartels, 24 INT'L J. INDUS. ORG. 1241 (2006); Bigoni et al., supra note 42; Jay Pil Choi \& Heiko Gerlach, Global Cartels, Leniency Programs and International Antitrust Cooperation, 30 INT'L J. INDUS. ORG 528 (2012); Harrington, Jr., supra note 10; Harrington, Jr. \& Chang, supra note 127; Christopher R. Leslie, Antitrust Amnesty, Game Theory, and Cartel Stability, 31 J. CoRP. L. 453 (2006); Leslie M. Marx \& Claudio Mezzetti, Effects of Antitrust Leniency on Concealment Effort by Colluding Firms, 2 J. ANTITRUST ENF'T 305 (2014).

129. See generally Luca Aguzzoni et al., The Effect of EU Antitrust Investigations and Fines on a Firm's Valuation, 61 J. INDUS. ECON. 290 (2013).

130. Id. 
to collusion. ${ }^{131}$ Similarly, cartel guidelines promulgated by a number of competition authorities also provide guidance on how best to create anti-cartel programs for firms. ${ }^{132}$

It is possible that the increasing number of antitrust regimes that actively prosecute cartels, as well as European enforcement, ${ }^{133}$ means fewer global cartels. Compounding the increase in cartel enforcement globally is the impact of how other areas of compliance may be leading to better mechanisms for compliance that may impact cartel detection internally such as anti-bribery and audit related compliance involving accounting fraud. ${ }^{134}$ Thus, the more significant sanctions may be lowering the cartel crime rate. ${ }^{135}$

\section{B. Cartels Have Gotten Smarter and Avoided Detection}

Under this scenario, cartels are still formed but are more complex, endogenizing the stricter antitrust screens and scrutiny. It may be that firms have learned to game leniency and are able to use leniency to punish competitors and/or harden existing cartels. ${ }^{136}$ In such circumstances, firms are more likely to come to agreement to collude but need not do so in terms of express collusion but mere tacit agreement.

Tacit agreement through price signaling may have become easier over time given changes in case law, particularly since Twombly. ${ }^{137}$ Twombly has made it more difficult for plaintiffs to overcome pre-trial motions. ${ }^{138}$ The increased difficulty of private plaintiffs to bring successful cases against tacit agreement in conjunction with aggressive prosecution of direct evidence through leniency pushes rational firms to change their collusion strategy to a murkier legal area of tacit agreement in which "plus" factors that distinguish agreement from mere

131. Anne Riley \& D. Daniel Sokol, Rethinking Compliance, 3 J. Antitrust EnF'T 31, 54 (2015).

132. Id. at 45 .

133. Pierre Cremieux \& Edward A. Snyder, Enforcement of Anticollusion Laws Against Domestic and Foreign Firms, 59 J.L. \& ECON. 775, 776 (2016).

134. See Riley \& Sokol, supra note 131, at 31 .

135. Oren Bar-Gill \& Alon Harel, Crime Rates and Expected Sanctions: The Economics of Deterrence Revisited, 30 J. Legal STUD. 485, 485 (2001) ("A HIGHER expected sanction lowers the crime rate. This intuitive cornerstone of deterrence theory has garnered extensive theoretical and empirical research."). But see Lucian Arye Bebchuk \& Louis Kaplow, Optimal Sanctions When Individuals Are Imperfectly Informed about the Probability of Apprehension, 21 J. LEGAL STUD. 365, 365-366 (1992) (suggesting that individual criminal actors respond to deterrence theories).

136. D. Daniel Sokol, Cartels, Corporate Compliance, and What Practitioners Really Think About Enforcement, 78 ANTITRUST L.J. 201, 203 (2012).

137. Bell Atlantic Corp. v. Twombly, 550 U.S. 544, 559 (2007) ("[I]t is only by taking care to require allegations that reach the level suggesting conspiracy that we can hope to avoid the potentially enormous expense of discovery in cases with no 'reasonably founded hope that the [discovery] process will reveal relevant evidence' to support a $\S 1$ claim.”). See generally William H. Page, Pleading, Discovering, and Proving A Sherman Act Agreement: Harmonizing Twombly And Matsushita, 82 ANTITRUST L.J. 123, 124 (2018).

138. Page, Pleading, supra note 137, at 124. 
interdependence are not always clear. ${ }^{139}$ There are both strict ${ }^{140}$ and more lenient ${ }^{141}$ readings of Twombly across circuits with regard to how much additional evidence is necessary.

We suggest that the new work on partial ownership is encouraging information leakage in ways that may (or may not) be illegal but facilitate collusion. A series of new papers suggest that partial ownership is correlated to greater collusion as a result of ownership by various mutual funds and other passive investors. ${ }^{142}$ In this literature, the claims are mixed. Some claims suggest that there is more than just mere tacit collusion but some signaling of behavior that might lead to greater coordination and higher prices. ${ }^{143}$

If firms have also become more sophisticated in their explicit collusion as a result of partial ownership, then this may explain why total government prosecutions have fallen below more recent levels of enforcement.

\section{Increased (Legal) Tacit Collusion}

Posner explained that the ability of firms to lawfully, tacitly collude "appears to be common, each tacit colluder reckoning that in all likelihood the others will see the advantages of hanging together rather than hanging separately."144 Shifts in market structure have decreased the risk of certain forms of collusion. Gradually, as empirical work on antitrust markets bears out, at least in a number of markets there has been increased concentration in recent decades. ${ }^{145}$ As markets become more concentrated, it may be easier for firms to pursue strategies of mere tacit collusion. ${ }^{146}$ Data analytics potentially may make it easier to hide cartels because of massive information dumps and ability to signal more effectively through tacit collusion or explicitly through algorithms. ${ }^{147}$

Another strand of the partial ownership literature lacks a causal story of how this price signaling is occurring but argues that even mere tacit collusion is

139. In re Ins. Brokerage Antitrust Litig., 618 F.3d 300, 323 (3d Cir. 2010) ("[P]laintiffs . . must allege facts that, if true, would establish at least one 'plus factor,' since plus factors are, by definition, facts that 'tend[] to ensure that courts punish concerted action - an actual agreement - instead of the unilateral, independent conduct of competitors.'”).

140. See In re Musical Instruments \& Equip. Antitrust Litig., 798 F.3d 1186, 1193-94 (9th Cir. 2015); Name.Space, Inc. v. Internet Corp. for Assigned Names and Numbers, 795 F.3d 1124, 1129-31 (9th Cir. 2015); Burtch v. Milberg Factors, Inc., 662 F.3d 212, 229 (3d Cir. 2011).

141. See SD3, LLC v. Black \& Decker U.S., Inc., 801 F.2d 412, 418 (4th Cir. 2015); Evergreen Partnering Grp., Inc. v. Pactiv Corp., 720 F.3d 33, 50 (1st Cir. 2013); Starr v. Sony BMG Music Entm’t, 592 F.3d 314, 325 (2d Cir. 2010).

142. Einer Elhauge, Horizontal Shareholding, 129 HARV. L. REV. 1267, 1267-78 (2016).

143. Gaurab Aryal et al., Public Communication and Collusion in the Airline Industry 10 (Univ. of Va., Working Paper, Feb. 12, 2018).

144. In re Text Messaging Antitrust Litig., 782 F.3d 867, 877 (7th Cir. 2015).

145. Sam Peltzman, Industrial Concentration Under the Rule of Reason, 57 J.L. \& ECON. S101, S118 (2014) (finding increased concentration in American manufacturing).

146. See Louis Kaplow, Competition Policy and Price FiXing 133-45 (2013).

147. Salil K. Mehra, US v. Topkins: Can Price Fixing Be Based on Algorithms?, 7 J. EUR. COMPETITION L. \& PRAC. 470, 473 (2016). 
anticompetitive. ${ }^{148}$ If this literature is correct, firms have become more sophisticated in their ability to legally signal behavior in the case of tacit collusion.

\section{Shift From Greater Emphasis on Domestic Cartels to International Cartels}

The Reagan enforcement boom in cartels was largely related to state and federal government bid-rigging cases. ${ }^{149}$ Many of these cases involved smaller cartels, ${ }^{150}$ based on the size of the fine. Starting under Clinton, the emphasis has been on prosecution of larger international cartels. ${ }^{151}$ This trend continues to the present. ${ }^{152}$ But less total enforcement in terms of number of cases at present may be partly due to lack of emphasis on domestic cartels (so fewer are caught in this category). The shutdown of the DOJ field offices in Atlanta, Philadelphia, and Cleveland may contribute to this asymmetry in terms of cartel size. ${ }^{153}$

\section{E. Private Plaintiffs and States Have not Picked up the Local Bid Rigging and so This Goes Undetected}

The majority of antitrust litigation is private rather than public. ${ }^{154}$ In this Article, we analyze the impact of public enforcement. This may not reflect the total dynamic of antitrust litigation. ${ }^{155}$ The relationship between public and private enforcement is complex, including in the area of collusion. It could be the case in which private enforcement is a substitute for private enforcement. That is, the DOJ may be resource-constrained ${ }^{156}$ or under-aggressive in its cartel pros-

148. See Jonathan B. Baker, Overlapping Financial Investor Ownership, Market Power, and Antitrust Enforcement: My Qualified Agreement with Professor Elhauge, 129 HARV. L. REV. F. 212, 221 (2016); see also José Azar et al., Anticompetitive Effects of Common Ownership, 73 J. FIN. 1513 (2018); José Azar et al., Ultimate Ownership and Bank Competition (May 4, 2019), (unpublished manuscript) (http://ssrn.com/abstract=2710252). But see Daniel P. O'Brien \& Keith Waehrer, The Competitive Effects of Common Ownership: We Know Less than We Think, 81 ANTITRUST L.J. 729 (2017).

149. Ghosal, Regime shift, supra note 105 , at 771.

150. See e.g., Robert H. Porter \& J. Douglas Zona, Detection of Bid Rigging in Procurement Auctions, 101 J. POL. ECON. 518, 523 (1993).

151. Brent Snyder, Deputy Assistant Attorney Gen., Dep't of Justice, Deputy Assistant Attorney General Brent Snyder Delivers Remarks at the Sixth Annual Chicago Forum on International Antitrust (June 8, 2015), https://www.justice.gov/opa/speech/deputy-assistant-attorney-general-brent-snyder-delivers-remarks-sixth-annual-chicago ("The Corporate Leniency Program revolutionized cartel enforcement, led to the successful prosecution of many long-running and egregious international cartels ....”).

152. Id.

153. See generally Ghosal \& Sokol, supra note 13.

154. Daniel A. Crane, Optimizing Private Antitrust Enforcement, 63 VAND. L. REV. 675, 675 (2010).

155. Id. at 678-98; Robert H. Lande \& Joshua P. Davis, Benefits from Private Antitrust Enforcement: An Analysis of Forty Cases, 42 U.S.F. L. REV. 879, 905 (2008).

156. Connor, supra note 111, at 265 ("Without significant increases in cartel detection, in the levels of expected fines or civil settlements, or expansion in the standing of buyers to seek compensation, international price fixing will remain rational business conduct.”). 
ecutions, taking safer cases based on leniency rather than investigating the possibility for collusion either based on news reports or based on empirical screens. ${ }^{157}$

\section{F. State Enforcement is not Active Enough in Cartel Prosecutions}

State antitrust enforcement could play a substitute role for federal enforcement of cartels. Recent work regarding state antitrust enforcement, however, suggests that collusion is not an enforcement priority. ${ }^{158}$ Rather, enforcement tends to focus on national related cases that are high profile and seem to be subject to Virginia School public choice rent seeking concerns. ${ }^{159}$ Part of this mismatch regarding cartels may also be due to the fact state attorneys general differ in their resources and capabilities vis-à-vis the DOJ Antitrust Division. States have fewer such resources. ${ }^{160}$

Because of resource constraints and a concern that bringing cases involving tacit agreement are costly and difficult to prove, cases involving tacit agreement are cases that private plaintiffs bring rather than the government. Not all potential tacit agreement cases are brought because of the economics of litigation. The cost to defend antitrust claims may be significant for the firm defending them. Whereas it is relatively cheap to bring on follow-on actions to government cases because of a free riding effect of government investigations or settlements, ${ }^{161}$ bringing a private case is more costly. The appeal of private cases is the possibility of treble damages. In this setting, antitrust enforcement allows for substitutability of private actions for government claims in the case of collusion. ${ }^{162}$

\section{G. Technological Innovation}

Technological innovation may be at play in impacting the number of cartel prosecutions. The effects of technological change may be in one or both directions. On the one hand, amassing significant data may make it easier to tacitly collude lawfully. Similarly, upstream or downstream firms may be better able, through screening technology, ${ }^{163}$ to uncover irregularities that may be collusive

157. See Rosa M. Abrantes-Metz \& D. Daniel Sokol, The Lessons from Libor for Detection and Deterrence of Cartel Wrongdoing, 3 HARV. Bus. L. REV. ONLINE 10, 11 (2012).

158. See John A. Dove, Antitrust Enforcement by State Attorneys General: Institutional, Legal and Political Considerations, 16 BUS. \& POL. 291, 292-93 (2014); Robert M. Feinberg, State Antitrust Enforcement in the US and Implications for Small Business Entry and Relocation, 46 APPLIED ECON. 769, 769 (2014); Robert M. Feinberg \& Thomas A. Husted, Do States Free Ride in Antitrust Enforcement?, 51 ECON. INQUIRY 997, 998 (2013).

159. See sources cited supra note 158 .

160. Robert W. Hahn \& Anne Layne-Farrar, Federalism in Antitrust, 26 HARV. J.L. \& PUB. POL'Y 877, $887-90$ (2003).

161. D. Daniel Sokol, The Strategic Use of Public and Private Litigation in Antitrust as Business Strategy, 85 S. CAL. L. REV. 689, 697 (2012).

162. David Besanko \& Daniel F. Spulber, Are Treble Damages Neutral? Sequential Equilibrium and Private Antitrust Enforcement, 80 Am. ECON. Rev. 870 (1990); Stephen W. Salant, Treble Damage Awards in Private Lawsuits for Price Fixing, 95 J. POL. ECON. 1326, 1326 (1987).

163. David Imhof, Econometric Tests to Detect Bid-Rigging Cartels: Does it Work?, 483 WORKING PAPERS SES, June 12, 2017, at 1, 13 . 
and directly renegotiate contractual terms with one or more suppliers in a way that does not disrupt supply chains but that remedies anti-competitive behavior. On the other hand, technology may make it easier to collude through price related algorithms. ${ }^{164}$ The evidence for these propositions regarding AI collusion and fighting it is rather scarce. ${ }^{165}$

\section{COMPARISON OF U.S. AND EUROPEAN COMMISSION CARTEL ENFORCEMENT}

In this Part, we draw attention to the fact that in the more recent periods international enforcement of cartels has gone up. In particular, the European Commission has been active in prosecuting high profile cartels, with relatively large increases in fines. While an extensive analysis of the international dimension is beyond the scope of this Article, we take a look at potential interrelationships between the U.S. and European Commission ("EC") cartel enforcement.

It is likely that developments in European enforcement may have impacted U.S. enforcement and vice versa. Though empirically it is challenging to isolate these dynamic effects, often with enforcement of the same cases, because of endogeneity concerns, in this Part we map out transformations in European cartel prosecutions to draw some parallels to the U.S. experience. While cartel enforcement has grown in other jurisdictions, in terms of fines (EC law does not provide for criminalization of cartel related behavior), the United States and the EC are the two most important jurisdictions for government enforcement. ${ }^{166}$ Outside of the U.S., private rights of action at present only play a role in the UK, Netherlands, and Germany. ${ }^{167}$ Criminalization plays a role in an increasing number of countries but few cartel members go to jail outside of the U.S. ${ }^{168}$

We briefly present a comparison of U.S. and European cartel enforcement. As the U.S. DOJ and the EC comprise the two largest cartel enforcement agencies, U.S. cartel prosecution likely does not operate in isolation of developments worldwide. One issue that we did not address in our earlier discussion is that some of the developments in U.S. cartel prosecutions and cartel detection, par-

164. Ariel Ezrachi \& Maurice E. Stucke, Artificial Intelligence \& Collusion: When Computers Inhibit Competition, 2017 U. ILL. L. REv. 1775, 1776 (2017); Salil K. Mehra, Antitrust and the Robo-Seller: Competition in the Time of Algorithms, 100 MINN. L. REv. 1323, 1324 (2016).

165. See generally Justin Johnson \& D. Daniel Sokol, Understanding Ai Collusion and COMPLIANCE, in CAMBRIDGE HANDBOOK OF COMPLIANCE (forthcoming), https://papers.ssrn.com/sol3/papers. cfm?abstract_id $=3413882$.

166. Martin Carree et al., European Antitrust Policy 1957-2004: An Analysis of Commission Decisions, 36 REV. INDUS. ORG. 97, 99-117 (2010).

167. See, e.g., D. Daniel Sokol, Daniel Crane \& Ariel Ezrachi, Global Antitrust Compliance HANDBOOK (2014); Marianne Charrier \& Gordon Downie, UK and EU Developments in Collective Action Regimes for Competition Law Breaches, 35 Euro. CompetiTion L. Rev. 369, 369-75 (2014); Sebastian Peyer, Private Antitrust Litigation in Germany From 2005 to 2007: Empirical Evidence, 8 J. COMPETITION L. \& ECON. 331, 331 (2012); Barry J. Rodger, Why Not Court? A Study of Follow-on Actions in the UK, 1 J. ANTITRUST ENFORCEMENT 104, 104-05 (2013).

168. Caron Beaton-Wells, Criminal Sanctions for Cartel Conduct: The Leniency Conundrum, $13 \mathrm{~J}$. COMPETITION L. \& ECON. 125, 125-26 (2017). 
ticularly in the later period of the sample, may be related to events in other jurisdictions. In particular, some of the U.S. prosecutions could be related to developments in European cartel prosecutions and vice versa.

In this Part, we briefly note some issues, present aggregate enforcement data, and conduct some empirical estimation to shed light on this issue.

European cartel enforcement has gone through changes in prosecution tools, which we briefly summarize. The first legal prohibition against collusion was in the 1957 Treaty of Rome. ${ }^{169}$ Cartel enforcement for decades was rather sparse and penalties relatively meaningless with little deterrence value. ${ }^{170}$ Significant fines and prosecution of cartels did not begin until after the First Leniency Notice in $1996 .{ }^{171}$ Shortly thereafter in 1998 , the Commission issued its First Guidelines ${ }^{172}$ on the method of setting fines. That was the same year as the first leniency applicant (Tate \& Lyle) in the sugar cartel. ${ }^{173}$

European policy initiatives increased during the 2000s, perhaps in part in response to developments in the U.S., and also recognizing the significant welfare losses that were generated by price-fixing agreements between firms.${ }^{174}$ The EC provided its Second Leniency Notice in $2002,{ }^{175}$ which provided immunity for ongoing investigations. Cartel enforcement became decentralized under Regulation 1/2003, ${ }^{176}$ which allowed then Article 81 application by national courts and agencies. The regulation also increased powers of investigation and set up the European Competition Network ("ECN"). ${ }^{177}$ In 2006, DG Competition introduced its Second Guidelines on the method of setting fines, ${ }^{178}$ the Third Leniency Notice, ${ }^{179}$ which attempted to increase transparency (and create a marker system), and the ECN Model Leniency program (to harmonize leniency across the EU). ${ }^{180}$ In 2008, DG Competition introduced its settlement notice, which

169. See Treaty Establishing the European Economic Community art. 83, Mar. 25, 1957, 298 U.N.T.S. 11. The Treaty of Rome has since evolved into the TFEU, which was signed in 2007 and is the current governing treaty of the European Union. See Consolidated Version of the Treaty on the Functioning of the European Union, May 9, 2008, 2008 O.J. (C 115) 47.

170. See Ghosal \& Sokol, Policy Innovations, supra note 11, at 406-07.

171. Commission Notice on Immunity from Fines and Reduction of Fines in Cartel Cases, ๆ 6, 2006 O.J. (C 298) 17.

172. Guidelines on the Method of Setting Fines Imposed Pursuant to Article 23(2)(a) of Regulation No 1/2003, Jan. 14, 1998, 2006 O.J. (C 210) 2.

173. Massimo Motta \& Michele Polo, Leniency Programs and Cartel Prosecution, 21 INT'L J. INDUS. ORG. 347,372 (2003).

174. Id. at 427 .

175. Commission Notice on Immunity from Fines and Reduction of Fines in Cartel Cases, Feb. 14, 2002, 2002 O.J. (C 45) 5.

176. Council Regulation (EC) 1/2003 of 16 December 2002 on the Implementation of the Rules on Competition Laid Down in Articles 81 and 82 of the Treaty, art. 21, 2002 O.J. (L 1) 1.

177. Id. at 4 .

178. Guidelines on the Method of Setting Fines Imposed Pursuant to Article 23(2)(a) of Regulation No 1/2003, Jan. 9, 2006, 2006 O.J. (C 210) 2, 2.

179. Commission Notice on Immunity from Fines and Reduction of Fines in Cartel Cases, ๆ 6, 2006 O.J. (C 298) 11, 17.

180. European COMPETITION NETWORK, ECN MOdel LeNIENCY PROGRAMME, http://ec.europa.eu/competition/ecn/model_leniency_en.pdf. 
provided a $10 \%$ discount to participating firms. ${ }^{181}$ The first settlement case was in 2010. ${ }^{182}$ Finally, in 2012, the EU introduced its Second ECN Model Leniency program. ${ }^{183}$

The empirical literature on European cartel enforcement is relatively small. The evidence to date suggests a similar trend in enforcement to that of the United States. ${ }^{184}$

Figure 11: Total EC CARTEL CASES

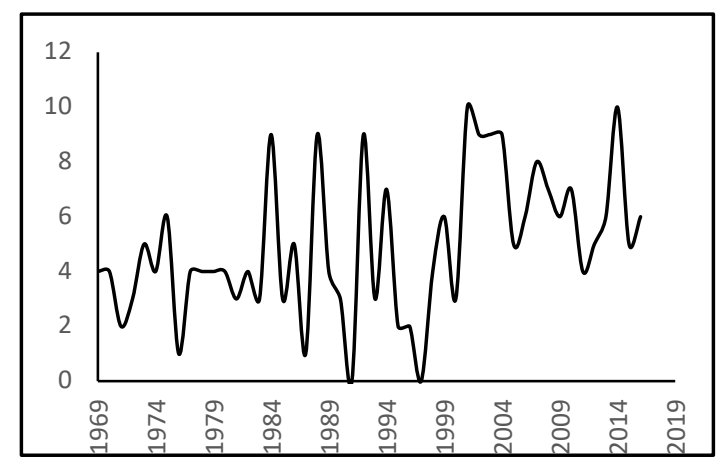

Figure 12: EC Cartel Fines Per Case (Real 2010\$, ’000)

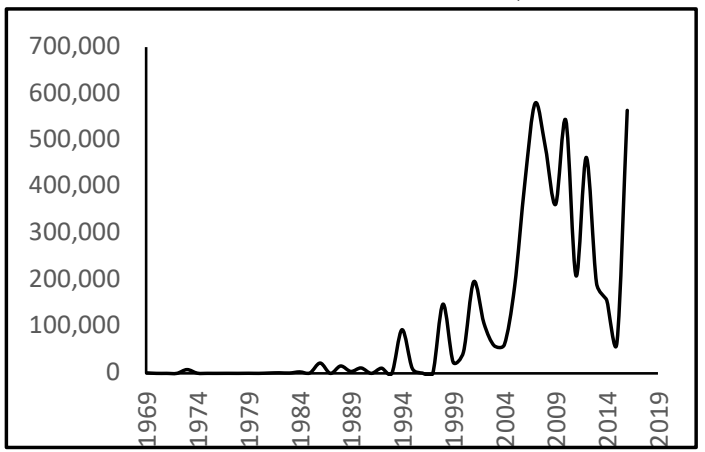

To briefly overview the data and make some comparisons between the U.S. and EC, we present a few figures. In Figure 11 and Figure 12 we display the total number of EC cartel cases and the fines per cartel, respectively. The time-path of the fines-per-cartel case is relatively similar to that of the U.S., with fines rising dramatically after around the year 2000 . Yet, the number of cartels prosecuted is very low: the average over the full sample period is only 4.5 cartels per year. The highest observation is ten cartels prosecuted in 2001 and ten prosecutions in 2014. These numbers are vastly lower than the U.S. sample mean of

181. Cartel Case Settlement, EUROPEAN COMMISSION, https://ec.europa.eu/competition/cartels/legislation/cartels_settlements/settlements_en.html (last visited Jan. 20, 2020).

182. Id.

183. European COMPetition Network, ECN Model LenienCy Programme (2012).

184. Aguzzoni et al., supra note 129, at 291; Carree et al., supra note 166, at 99-100; Leslie M. Marx et al., Antitrust Leniency with Multi-Market Colluders, 7 AM. ECON. J. 205 (2015); Maarten Pieter Schinkel, Effective Cartel Enforcement in Europe, 30 WORLD COMPETITION 539, 540-44 (2007); Andreas Stephan, An Empirical Assessment of the European Leniency Notice, 5 J. COMPETITION L. \& ECON. 537, 540-43 (2008). 
approximately forty-two per year, with a high of ninety-six prosecuted in 1984 . In Figure 13 we display the ratio of EC to U.S. cartel prosecutions.

\section{Figure 13: Ratio of EC to U.S. CARTEl CASES}

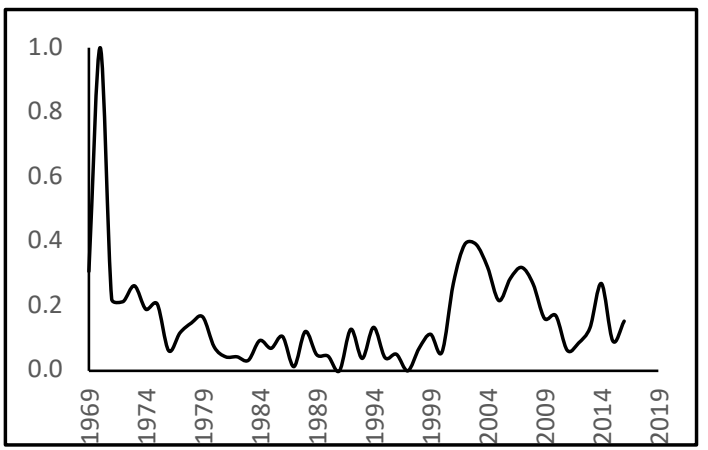

The argument that EU Member States have their own cartel prosecutions is unlikely to explain this gaping difference as one can, in a similar vein, argue that the individual U.S. states also prosecute cartels with some states having an active antitrust enforcement agenda.

Finally, in Figure 14, we examine the ratio of total EC cartel fines per case to the U.S. cartel fines per case. This presents a starkly different picture, with the average EC fine being an order of magnitude greater than in the U.S.

Figure 14: Ratio of Total EC CARTEl Fine Per CASE to U.S. Fine PER CASE

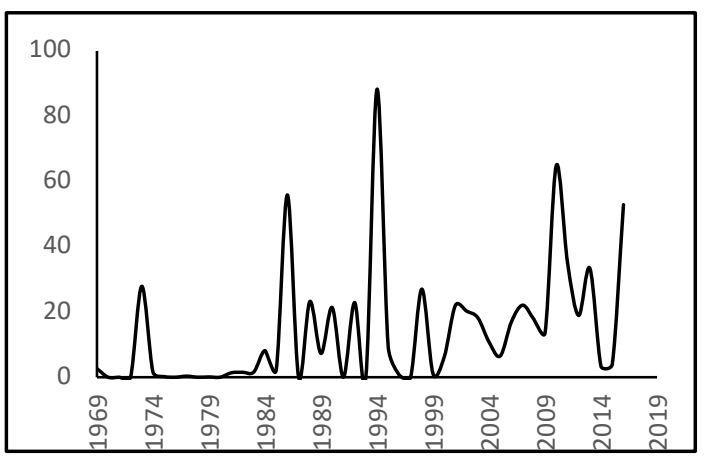

The overall EC versus U.S. comparisons look a bit puzzling, and the aggregated data that we use do not lend themselves to a clear framework for econometric analysis to examine the dynamic interlinkages. Perhaps the better solution for examining EC-U.S. dynamics is to examine specific cases that each jurisdiction prosecuted, examine their origins, and then analyze whether one jurisdiction may have piggybacked on the other for specific cases or if the prosecution was coordinated from the beginning or benefitted later in time from the other competition authority. 


\section{A. Examination of Dynamic Interrelationships Between U.S.-EC Cartel Enforcement}

While our data are aggregate, we estimate some dynamic regression models to examine whether there are interlinkages between U.S. and EC cartel enforcement. For example: Do U.S. (EC) cartel prosecutions increase when EC (U.S.) prosecutions increase? Do U.S. (EC) fines show an increase when EC (U.S.) fines increase? The basic idea is that if there are close relationships (in the aggregate) between the cases prosecuted across the two jurisdictions, then the answers to the above questions are likely to be: yes. If the aggregate data mask substantial heterogeneity that may be case-specific, however, then regressions based on aggregate data may not show clear relationships. With this caveat in mind, below we present three sets of regressions related to: (a) total cartel prosecutions; (b) total cartel fines; and (c) cartel fines per case.

We estimate bivariate autoregressive-distributed lag models, with one autoregressive lag and two distributed lags of the form:

$$
[2] X(1)_{t}=\alpha_{0}+\alpha_{1} \text { Trend }+\alpha_{2} X(1)_{t-1}+\alpha_{3} X(2)_{t-1}+\alpha_{4} X(2)_{t-2}+\varepsilon_{t} \text {. }
$$

The specifications we estimate are in logarithmic-levels, implying that the estimated coefficients can be interpreted as elasticities. ${ }^{185}$ The specification (2) can be interpreted as follows. For example, in specification (2), X(1) could be U.S. cartel cases, and $X(2) \mathrm{EC}$ cartel cases. The specification implies that after controlling for any general time trend in the data (Trend), we can examine whether past U.S. cartel cases affect current cases, and whether lagged EC cartels cases affect current U.S. cases. This is a fairly standard bivariate specification to examine intertemporal interlinkages between $X(1)$ and $X(2)$. Similarly, $X(1)$ and $X(2)$ could be U.S. total cartel fines and EC total cartel fines, respectively, or U.S. fines per cartel, and EC fines per cartel, respectively.

In specification (2), we include a linear time trend as some of the cartel enforcement variables (noted in Figures 1 through 8) show trends. Omitting the trend variable, when a trend is present, will lead to biased coefficient estimates. Including a trend variable when no trend is present does not diminish the model as the included trend variable will be statistically insignificant. So estimating the specifications by including a trend variable makes it more general.

In reporting the estimates below, we use OLS to estimate the parameters of (2). We note two points before presenting the estimates: (a) our experiments with deeper lags of $X(1)$ and $X(2)$ did not reveal any new insights from those reported below; and (b) we also experimented with using the Seemingly Unrelated Regressions estimator to estimate the parameters of (00). Our results were virtually identical to those reported below.

185. The conceptual and theoretical underpinnings of this framework are spelled out in, for example, David Hendry et al., Dynamic Specification, in HANDBOOK OF ECONOMETRICS (Zvi Griliches \& Michael Intriligator eds., 1983); John Kennan, The Estimation of Partial Adjustment Models with Rational Expectations, 47 ECONOMETRICA 1441, 1441 (1979). 
Table 3 presents the cross-relationship between U.S. and EC cartel cases. Our estimates reveal that, based on aggregate data we use, there is no statistically significant interrelationship between U.S. and EC cartel cases. In the dynamic specifications reported below, the only significant coefficient is for USCases t- , indicating a degree of persistence in U.S. cartel prosecutions.

TABLE 3: U.S. AND EC CARTEL CASES

\begin{tabular}{|l|c|c|}
\hline & 1. .nUSCases $_{t}$ & 2. .nECCases $_{t}$ \\
\hline Constant & 5.231 & $-48.27^{* *}$ \\
& $(0.455)$ & $(0.023)$ \\
\hline Trend & -0.002 & $0.025^{* *}$ \\
& $(0.564)$ & $(0.021)$ \\
\hline lnUSCases $_{t-1}$ & $0.714^{* * *}$ & 0.404 \\
& $(0.001)$ & $(0.297)$ \\
\hline $\operatorname{lnUSCases}_{t-2}$ & - & -0.853 \\
& & $(0.153)$ \\
\hline $\operatorname{lnECCases}_{t-1}$ & $-0.039^{* *}$ & -0.033 \\
& $(0.046)$ & $(0.611)$ \\
\hline $\operatorname{lnECCases}_{t-2}$ & -0.015 & - \\
\hline $\bar{R}^{2}$ & $(0.237)$ & -0.034 \\
\hline $\mathrm{P}$ & 0.710 & -0.020 \\
\hline
\end{tabular}

Notes: (a) all specifications are estimated using data over 1969-2016; (b) $\ln$ denotes natural logarithm; (c) $p$-values calculated from robust standard errors are in parentheses; (d) the asterisks *,**, and $* * *$ represent significance at the $10 \%, 5 \%$, and $1 \%$ levels, respectively; and (e) $\rho$ is the estimate of the first-order autocorrelation.

Next we estimate a similar bivariate specification, but with total U.S. and EC cartel fines. These estimates are presented in Table 4. Examining the esti-

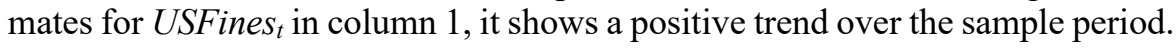
As the coefficient on USFinest-1 is significant, it shows persistence in U.S. fines data. Finally, the only cross-relational coefficient that is significant is

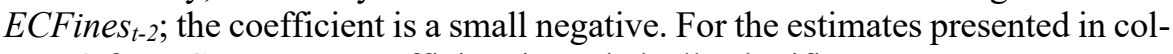
umn 2 for ECFines, no coefficient is statistically significant. 
TABLE 4: U.S. AND EC TOTAL FINES

\begin{tabular}{|l|c|c|}
\hline & 1. .nUSFines $_{t}$ & 2. lnECFines $_{t}$ \\
\hline Constant & $-176.336^{* * *}$ & -326.696 \\
& $(0.001)$ & $(0.398)$ \\
\hline Trend & $0.092^{* * *}$ & 0.154 \\
& $(0.001)$ & $(0.445)$ \\
\hline lnUSFines $_{t-1}$ & $0.355^{* * *}$ & 1.890 \\
& $(0.009)$ & $(0.122)$ \\
\hline lnUSFines $_{t-2}$ & - & 0.659 \\
& & $(0.529)$ \\
\hline lnECFines $_{t-1}$ & -0.012 & $-0.238^{*}$ \\
& $(0.314)$ & $(0.074)$ \\
\hline lnECFines $_{t-2}$ & $-0.032^{*}$ & - \\
& $(0.075)$ & 0.407 \\
\hline $\bar{R}^{2}$ & 0.835 & -0.004 \\
\hline $\mathrm{P}$ & 0.005 & \\
\hline
\end{tabular}

Notes: (a) all specifications are estimated using data over 1969-2016; (b) $\ln$ denotes natural logarithm; (c) p-values calculated from robust standard errors are in parentheses; (d) the asterisks *,**, and *** represent significance at the $10 \%, 5 \%$, and $1 \%$ levels, respectively; and (e) $\rho$ is the estimate of the first-order autocorrelation.

Finally, in Table 5, we estimate bivariate specifications using data on U.S. and EC fines per cartel, as opposed to total fines in the previous table. In contrast to the total fines estimates in the above table, the time trend is significant for both U.S. and EC fines per cartel, and the estimated elasticity is much larger for EC. As in some of the above estimates, the lagged dependent variable, the coefficient

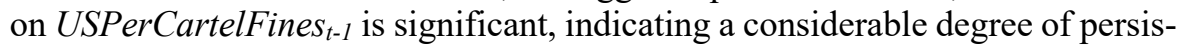
tence. Aside from these effects, no other coefficient is significant.

TABle 5: U.S. AND EC PER CARTEL Fines

\begin{tabular}{|c|c|c|}
\hline & 1. InUSPerCartelFines $_{t}$ & 2. lnECPerCartelFines $_{t}$ \\
\hline Constant & $\begin{array}{c}-154.661 * * * \\
(0.001)\end{array}$ & $\begin{array}{c}-807.840 * * * \\
(0.001)\end{array}$ \\
\hline Trend & $\begin{array}{c}0.079 * * * \\
(0.001)\end{array}$ & $\begin{array}{c}0.409 * * * \\
(0.011)\end{array}$ \\
\hline lnUSPerCartelFines $_{t-1}$ & $\begin{array}{c}0.403 * * * \\
(0.003)\end{array}$ & $\begin{array}{c}0.461 \\
(0.637) \\
\end{array}$ \\
\hline lnUSPerCartelFines $_{t-2}$ & - & $\begin{array}{c}-0.389 \\
(0.668)\end{array}$ \\
\hline lnECPerCartelFines $_{t-1}$ & $\begin{array}{l}-0.011 \\
(0.466) \\
\end{array}$ & $\begin{array}{l}-0.183 \\
(0.199) \\
\end{array}$ \\
\hline lnECPerCartelFines $_{t-2}$ & $\begin{array}{l}-0.020 \\
(0.332) \\
\end{array}$ & - \\
\hline $\bar{R}^{2}$ & 0.786 & 0.421 \\
\hline $\mathrm{P}$ & -0.017 & -0.011 \\
\hline
\end{tabular}

Notes: (a) all specifications are estimated using data over 1969-2016; (b) $\ln$ denotes natural logarithm; (c) $p$-values calculated from robust standard errors are in parentheses; (d) the asterisks *,**, and $* * *$ represent significance at the $10 \%, 5 \%$, and $1 \%$ levels, respectively; and (e) $\rho$ is the estimate of the first-order autocorrelation. 
Our overall conclusion from the estimation exercise above is that we do not find any obvious interrelationships between U.S. and EC cartel prosecutions or fines, based on aggregate enforcement data. This is not to say there are no dynamic interrelationships. It is more likely that if we study the same issue on a cartel-by-cartel basis, we may well find that specific cartel prosecutions in the U.S. (EC) lead to sharing of information and prosecutions in EC (U.S.), with consequent implications for fines and other penalties. If the dynamic case-specific linkages are few relative to the aggregate enforcement data, then aggregate estimation of the sort using specification (2) may not reveal clear interdependence. This line of inquiry, using a combination of case-specific information and aggregate enforcement statistics can be an interesting future extension.

\section{CONCLUSION}

Cartel prosecution numbers have shifted over time as a result of institutional changes in the DOJ Antitrust toolkit. The three primary changes have been increased fines, increased incarceration, and the introduction of the revised leniency program. These changes in tools have led to potential change to which would-be cartel members respond. A growing internationalization of cartel enforcement also increases the probability of detection and the amount of both government and private damages that firms pay for their illegal behavior. Would-be and current cartel members may be adapting to the current structure of cartel enforcement. Further tweaks to the enforcement system are likely to be introduced for enforcement to keep up with collusion.

Overall, we find that cartel prosecution has shifted over time to a larger set of penalties for violations but with fewer total cartels caught. These results paint an incomplete picture. They do not directly explain whether or not cartel prosecutions have made collusion more or less difficult, how mechanisms for coordination across firms for collusive behavior may be changing in response to prosecutions, nor do they capture how doctrinal changes in tacit agreement or technological innovation may be shifting what may be observed. Yet, our findings do allow for observations across changes in the economy, presidential administrations, political parties, merger waves, government enforcement in Europe, and other factors to fill in important gaps as to at least some attributes of the overall enforcement picture. The overall enforcement profile continues to change and will require ongoing qualitative and quantitative empirical study to better inform policy decisions. 
